\title{
Electrochemical Corrosion of Ultra-high Strength Carbon Steel in Alkaline Brines Containing Hydrogen Sulfide
}

Ruishu Feng ${ }^{\mathrm{a}, \mathrm{b}}$, Justin Beck ${ }^{\mathrm{b}}$, Margaret Ziomek-Moroz ${ }^{\mathrm{c}, *}$, Serguei N. Lvov ${ }^{\mathrm{a}, \mathrm{b}, \mathrm{d}, \uparrow}$

${ }^{a}$ Department of Energy and Mineral Engineering, The Pennsylvania State University, University Park, PA 16802, USA

${ }^{\mathrm{b}}$ The EMS Energy Institute, The Pennsylvania State University, University Park, PA 16802, USA

${ }^{c}$ U.S. Department of Energy, National Energy Technology Laboratory, 1450 Queen Avenue SW, Albany, OR 97321, USA

${ }^{d}$ Department of Materials Science and Engineering, The Pennsylvania State University, University Park, PA 16802, USA

\begin{abstract}
Electrochemical corrosion of ultra-high strength carbon steel UD-165 was investigated using in-situ electrochemical techniques in $\mathrm{H}_{2} \mathrm{~S}$-containing alkaline brines (5 wt\% NaCl; $\mathrm{pH} 7.9,10.7$, and 12.4) with four $\mathrm{H}_{2} \mathrm{~S}$ partial pressures $\left(p_{\mathrm{H} 2 \mathrm{~S}}\right)$ from 0 to $69 \mathrm{kPa}$ at $85^{\circ} \mathrm{C}$. The effects of $\mathrm{pH}$ and $p_{\mathrm{H} 2 \mathrm{~S}}$ were studied in terms of corrosion rate $(\mathrm{CR})$, reaction mechanism, and corrosion products considering the Fe dissolution reactions with $\mathrm{HCO}_{3}^{-}(\mathrm{aq}), \mathrm{OH}^{-}(\mathrm{aq})$, and $\mathrm{HS}^{-}(\mathrm{aq})$. While $\mathrm{CR}$ generally decreased at higher $\mathrm{pH}$ and increased at higher $p_{\mathrm{H} 2 \mathrm{~S}}$, both accelerating and inhibiting effects of $\mathrm{H}_{2} \mathrm{~S}$ on $\mathrm{CR}$ were observed. High $\mathrm{CR}$ at $\mathrm{pH} 10.7$ correlated with a high ratio of $\mathrm{HS}^{-}(\mathrm{aq})$ to the total concentration of reactive anions. The
\end{abstract}

\footnotetext{
* Corresponding author: Tel: (541) 967-5943; fax: (541) 967-5880. Margaret.Ziomek-Moroz@ NETL.DOE.GOV

${ }^{\dagger}$ Corresponding author: Tel.: (814) 863-8377; fax: (814) 865-3248. E-mail address: lvov@ psu.edu
} 
corrosion products changed from iron carbonate and sulfides to iron oxides as the $\mathrm{pH}$ increased. Sulfur was detected mostly in the inner layer of corrosion products at $\mathrm{pH}$ 7.9.

Keywords: Electrochemical corrosion; Ultra-high strength carbon steel; Hydrogen sulfide; Alkaline corrosion; Corrosion product analysis.

\section{Introduction}

$\mathrm{H}_{2} \mathrm{~S}$ corrosion has been extensively studied due to its relevance to the oil and natural gas industry. High strength low-alloy carbon steels are commonly used for oil and natural gas exploration and production due to their mechanical properties and economical cost. However, $\mathrm{H}_{2} \mathrm{~S}$ has been found to make the carbon steels more susceptible to hydrogen induced cracking (HIC) or sulfide stress cracking (SSC), which could lead to catastrophic failure and drastic cost increase [1,2]. With the exploration of offshore wells going deeper to beyond $4572 \mathrm{~m}$, the carbon steels are exposed to higher pressure, higher temperature, and a more corrosive environment with the concentrations of acidic gases $\mathrm{CO}_{2}$ and $\mathrm{H}_{2} \mathrm{~S}$ increasing exponentially with depth [1]. Thus, it is important to understand $\mathrm{H}_{2} \mathrm{~S}$ corrosion of carbon steels in deep and ultra-deep wells to reduce and mitigate failure risks.

Electrochemical reactions and the formation of iron sulfides are two major factors of significance for $\mathrm{H}_{2} \mathrm{~S}$ corrosion. For the anodic reaction of Fe dissolution, Shoesmith et al. [3] proposed a chemisorptionoxidation mechanism for $\mathrm{H}_{2} \mathrm{~S}$ corrosion, and Ma et al. [4] proposed a similar mechanism with two consecutive electron transfer steps. These two mechanisms are both analogous to the Fe dissolution reaction mechanism with $\mathrm{OH}^{-}(\mathrm{aq})$ proposed by Bockris et al. [5]. With corrosion reactions taking place, the formation of iron sulfides could form corrosion product layers on the steel surface. The layers could be weakly or strongly protective, depending on the products and the morphology [6-9]. Mackinawite was usually observed at the initial stage as the base layer on the steel surface. At the spots where the 
base layer cracks, localized corrosion or pitting corrosion tends to occur $[3,10,11]$. For the hydrogen evolution reaction (HER) at the cathode region, a direct reduction reaction of $\mathrm{H}_{2} \mathrm{~S}$ or $\mathrm{HS}^{-}$(aq) was proposed in acidic conditions and could provide additional paths for the HER [12]. Moreover, it has been proposed that non-dissociated $\mathrm{H}_{2} \mathrm{~S}$ could have a catalytic effect following Reactions (1) and (2) [7].

$$
\begin{aligned}
& \mathrm{H}_{2} \mathrm{~S}(\mathrm{ad})+\mathrm{e}^{-}=\mathrm{H}(\mathrm{ad})+\mathrm{HS}^{-}(\mathrm{ad}) \\
& \mathrm{HS}^{-}(\mathrm{ad})+\mathrm{H}_{3} \mathrm{O}^{+}(\mathrm{aq})=\mathrm{H}_{2} \mathrm{O}(\mathrm{l})+\mathrm{H}_{2} \mathrm{~S}(\mathrm{ad})
\end{aligned}
$$

The regeneration of $\mathrm{H}_{2} \mathrm{~S}$ is favorable in an acidic environment, as seen from Equation (2). However, a drilling fluid of $\mathrm{pH} 10$ to 12 is usually used in drilling practice to limit corrosion. Most of the previous studies were conducted from $\mathrm{pH} 3$ to 9 [6,13-20], and the data has been limited for $\mathrm{H}_{2} \mathrm{~S}$-containing conditions at relatively high $\mathrm{pH}$. High $\mathrm{pH}$ could alter the reaction paths for both anodic and cathodic reactions and also influence the formation of corrosion products.

UD-165 (UNS G41300), an ultra-high strength low-alloy carbon steel, was designed especially for ultra-deep drilling. At $20{ }^{\circ} \mathrm{C}$ and $\mathrm{H}_{2} \mathrm{~S}$ partial pressure $\left(p_{\mathrm{H} 2 \mathrm{~S}}\right)$ of $0.83 \mathrm{kPa}$, it was reported that fatigue crack growth was controlled by hydrogen diffusion at $\mathrm{pH}=7$, whereas some characteristics of stress corrosion cracking were observed at $\mathrm{pH}=12$ [21-23]. A spatial mapping study using a Scanning Kelvin Probe at the sub-mm scales by Schaller and Scully found a close correlation between pit formation and high hydrogen production in acidic corrosion [24]. Electrochemical corrosion reactions have a significant impact on the initiation and propagation of pits and cracking. From this perspective, in situ electrochemical measurements and ex situ surface analysis were conducted in the present work to study the electrochemical corrosion reactions in $\mathrm{H}_{2} \mathrm{~S}$-containing alkaline brines.

The results from the authors' previous study showed that the addition of $p_{\mathrm{H} 2 \mathrm{~S}}$ affected the corrosion rate of UD-165 in carbonate-buffered alkaline solutions, where the accelerating or retarding effect of $\mathrm{H}_{2} \mathrm{~S}$ varied with $\mathrm{pH}[25,26]$. Some researchers found that a significant amount of $\mathrm{HCO}_{3}{ }^{-}(\mathrm{aq})$ accelerated 
the anodic reaction $[27,28]$. However, a systematic and comprehensive study on corrosion reactions of UD-165 has not been done in deaerated brines containing $\mathrm{HCO}_{3}{ }^{-}(\mathrm{aq}), \mathrm{OH}^{-}(\mathrm{aq})$, and $\mathrm{HS}^{-}(\mathrm{aq})$. Therefore, the effects of $\mathrm{pH}$ and $p_{\mathrm{H} 2 \mathrm{~S}}$ were studied in the present work considering the reactions with $\mathrm{HCO}_{3}{ }^{-}(\mathrm{aq})$, $\mathrm{OH}^{-}(\mathrm{aq})$, and $\mathrm{HS}^{-}(\mathrm{aq})$ and in terms of corrosion rate (CR), corrosion mechanism, and corrosion products.

\section{Experimental}

\subsection{Material and sample preparation}

The investigated material was an ultra-high strength low-alloy carbon steel, grade UD-165 (UNS G41300), and its chemical composition is listed in Table 1 [29].

\section{Table 1}

The chemical composition (wt\%) of UD-165 [29].

\begin{tabular}{ccccccccc}
\hline $\mathrm{Fe}$ & $\mathrm{Cr}$ & $\mathrm{Mn}$ & $\mathrm{Mo}$ & $\mathrm{Al}$ & $\mathrm{Ni}$ & $\mathrm{Cu}$ & $\mathrm{Nb}$ & $\mathrm{Si}$ \\
\hline $\mathrm{Bal}$ & 0.79 & 0.88 & 0.67 & 0.03 & 0.81 & 0.19 & 0.02 & 0.26 \\
\hline $\mathrm{S}$ & $\mathrm{P}$ & $\mathrm{B}$ & $\mathrm{C}$ & $\mathrm{N}$ & $\mathrm{V}$ & $\mathrm{Sn}$ & $\mathrm{Ti}$ & \\
\hline 0.007 & $<0.005$ & $<0.005$ & 0.27 & 0.007 & 0.07 & $<0.01$ & $<0.01$ & \\
\hline
\end{tabular}

Steel samples were cut into $10 \times 20 \times 5 \mathrm{~mm}$ plates and then coated with epoxy so that only one $10 \times 20$ $\mathrm{mm}$ face was exposed to the solution. The exposed surface was ground with 600 and 800 grit SiC papers and then polished by 0.1 and 0.05 micron alumina polishing slurry to minimize the surface defects and keep the surface area as consistent as possible. After rinsing with propanol and distilled water, the steel samples were wiped dry and ready for the assembly. The wire attached to the steel sample was coated 
with shrinkable polytetrafluoroethylene (PTFE) tubing to avoid undesirable corrosion and short circuit with the autoclave.

\subsection{System setup}

The electrochemical measurements were carried out in a three-electrode system inside an autoclave. The working electrode was the carbon steel sample prepared as described in Section 2.1. The counter electrode was a platinum plate with dimensions of $10 \times 20 \times 1 \mathrm{~mm}$, which was prepared similarly to the working electrode. These two electrodes were held in place with the polished surfaces parallel to each other between two PTFE plates, which were tightened by two PTFE-coated screws. There was a spacing of $10 \mathrm{~mm}$ between the electrode surfaces. All of the leads from the electrodes were coated with shrinkable PTFE tubing.

The reference electrode was a double-junction silver-silver chloride ( $\mathrm{Ag} / \mathrm{AgCl})$ electrode specially designed to avoid contamination from the test solutions for a longer time. More details about the reference electrode can be found in Reference [25]. The solution inside the reference electrode was 5 wt $\% \mathrm{NaCl}(\mathrm{aq})$ solution to minimize the concentration gradient, and thus the junction potential, between the reference electrode and the test solutions. The diffusion potentials between the reference electrode and the test solutions were calculated according to the Henderson equation [30], and the values were within $1.5 \mathrm{mV}$. The reference electrode potential was calculated to be $0.19 \mathrm{~V}$ vs the standard hydrogen electrode (SHE) at $85{ }^{\circ} \mathrm{C}$.

The autoclave was a Parr 4560 system, which consisted of a $600 \mathrm{~mL}$ stainless steel reactor vessel, a PTFE liner which was used to contain the corrosive test solution, and the autoclave lid. Mounted in the lid were a thermocouple, a pressure transducer, and a polyether ether ketone (PEEK) tube for the injection of gas and solution. The thermocouple was protected from corrosion with a polymer coating. The temperature was controlled at $85^{\circ} \mathrm{C}$ by a heating mantle around the autoclave body and a digital 
controller connected with the thermocouple. The stainless steel stir rod and impeller of the magnetic stirrer were coated with epoxy to prevent undesired corrosion. PTFE compression glands were used to seal the wires coming out from the vessel. A schematic diagram of the autoclave system is shown in Fig. 1. The system temperature and pressure were recorded over the corrosion test using a computer. In situ electrochemical measurements were performed using Gamry Reference 600 potentiostat.

\subsection{Test conditions and experimental procedure}

The compositions of the test solutions are listed in Table 2. All of the chemicals used were ACS Reagent grade. There were three base solutions from \#1 to \#3, providing the $\mathrm{pH}$ range from 7.9 to 12.4. Four different $p_{\mathrm{H} 2 \mathrm{~S}}$ were investigated from 0 to $69 \mathrm{kPa}$. The $\mathrm{NaCl}$ concentration was equivalent to $5 \mathrm{wt} \%$ before adding the other chemicals.

The base solution was prepared with $250 \mathrm{~g}$ of deionized water at room temperature and then deaerated by bubbling with $\mathrm{N}_{2}$ for at least one hour. The deaerated solution was transferred to the autoclave by pressure difference after the autoclave vessel was flushed with $\mathrm{N}_{2}$. After the system was heated up to $85{ }^{\circ} \mathrm{C}, \mathrm{H}_{2} \mathrm{~S}$ was introduced to the system as a $\mathrm{H}_{2} \mathrm{~S} / \mathrm{N}_{2}$ gas mixture (10 vol\% $\left.\mathrm{H}_{2} \mathrm{~S}\right)$ through the tubing labelled as No. 6 in Fig. 1. Once the $p_{\mathrm{H} 2 \mathrm{~S}}$ in the autoclave reached the target pressure, i.e., $0.83 \mathrm{kPa}, 8.3 \mathrm{kPa}$ or $69 \mathrm{kPa}$, all of the valves were closed. Thus, the total amount of $\mathrm{H}_{2} \mathrm{~S}$ in the system was constant over the corrosion tests. According to the ideal gas law, the $\mathrm{H}_{2} \mathrm{~S}$ concentrations were estimated to be $2.63 \times 10^{-4} \mathrm{~mol} \mathrm{~kg}^{-1}, 2.63 \times 10^{-3} \mathrm{~mol} \mathrm{~kg}^{-1}$, and $2.19 \times 10^{-2} \mathrm{~mol} \mathrm{~kg}^{-1}$, respectively.

The solution $\mathrm{pH}$ at $85^{\circ} \mathrm{C}$ was computed using commercial modeling software [31], taking into account the system temperature, pressure, and components. According to Table 2, the $\mathrm{pH}$ increased from 7.9 to 12.4 from Solution \#1 to \#3 without $\mathrm{H}_{2} \mathrm{~S}$. The $\mathrm{pH}$ slightly decreased with the addition of $\mathrm{H}_{2} \mathrm{~S}$ due

to the dissociation of $\mathrm{H}_{2} \mathrm{~S}$. Note that when referring to the trend with $\mathrm{pH}$ in the following text, the $\mathrm{pH}$ of the base solutions were used for all of the $p_{\mathrm{H} 2 \mathrm{~S}}$, i.e., $\mathrm{pH} 7.9,10.7$, and 12.4. 
Linear polarization resistance (LPR) and electrochemical impedance spectroscopy (EIS) were performed every two hours over the exposure period. LPR was measured within $\pm 20 \mathrm{mV}$ around the measured open circuit potential (OCP), and the sweep rate was $1 \mathrm{mV} \mathrm{s}^{-1}$. EIS was measured within \pm 10 $\mathrm{mV}$ around the OCP over the frequency range at least from $300 \mathrm{kHz}$ to $5 \mathrm{mHz}$. The system was stirred at 525 RPM for 60 hours. After 60 hours, the stir rate was reduced to check the effect of mass transport in the bulk solution. Linear sweep voltammetry (LSV) was carried out at the stir rate of $525 \mathrm{RPM}$ at $p_{\mathrm{H} 2 \mathrm{~S}}=$ $0 \mathrm{kPa}$ and $69 \mathrm{kPa}$ with sweep rates of $5 \mathrm{mV} \mathrm{s}^{-1}$ and $2 \mathrm{mV} \mathrm{s}^{-1}$, respectively. The applied potential started around OCP for both the anodic LSV and the cathodic LSV, and the LSV plots were corrected for the solution resistance, $R_{\text {sol }}$, measured with EIS. After the corrosion exposure, the corrosion products on the steel surface were examined using scanning electron microscopy (SEM), energy-dispersive X-ray spectroscopy (EDS), X-ray diffraction (XRD), and cross-sectional analysis.

\section{Table 2}

Solution compositions $\left(\mathrm{mol} \mathrm{kg}{ }^{-1}\right.$ ) and the computed $\mathrm{pH}$ at different $p_{\mathrm{H} 2 \mathrm{~S}}$ at $85^{\circ} \mathrm{C}$.

\begin{tabular}{ccccccccc}
\hline Solution & $\mathrm{NaCl}$ & $\mathrm{NaHCO}_{3}$ & $\mathrm{Na}_{2} \mathrm{CO}_{3}$ & $\mathrm{NaOH}$ & $\begin{array}{c}\mathrm{pH}, \\
p_{\mathrm{H} 2 \mathrm{~S}}=0 \mathrm{kPa}\end{array}$ & $p_{\mathrm{H} 2 \mathrm{~S}}=0.83 \mathrm{kPa}$ & $p_{\mathrm{H} 2 \mathrm{~S}}=8.3 \mathrm{kPa}$ & $p_{\mathrm{H} 2 \mathrm{~S}}=69 \mathrm{kPa}$ \\
\hline$\# 1$ & 0.9 & 0.5 & 0 & 0 & 7.9 & 7.9 & 7.9 & 7.7 \\
$\# 2$ & 0.9 & 0 & 1 & 0 & 10.7 & 10.7 & 10.7 & 10.5 \\
$\# 3$ & 0.9 & 0 & 1 & 1 & 12.4 & 12.4 & 12.4 & 12.4 \\
\hline
\end{tabular}

\subsection{Calculation of the corrosion rate}


In a three-electrode cell, when the corrosion reaction is under activation control and the polarization is sufficiently small, the corrosion current density, $j_{\text {corr }}$, can be calculated according to the Stern-Geary equation as shown in Equation (3) [30,32,33].

$$
j_{\text {corr }}=\frac{b_{\mathrm{c}} b_{a}}{2.303 R_{\mathrm{pol}}\left(b_{\mathrm{c}}-b_{a}\right)}
$$

where $R_{\mathrm{pol}}$ is the area-specific polarization resistance; $b_{\mathrm{c}}$ and $b_{\mathrm{a}}$ are the cathodic and anodic Tafel slopes, respectively. $b_{\mathrm{c}}$ has a negative sign and $b_{\mathrm{a}}$ is positive. $R_{\mathrm{pol}}$ was obtained from LPR corrected for $R_{\text {sol }}$. Tafel slopes were calculated according to Equations (4) and (5), assuming the symmetry factor $\beta$ to be 0.5 .

$$
\begin{gathered}
b_{a}=\frac{2.303 R T}{n(1-\beta) F} \\
b_{\mathrm{c}}=\frac{2.303 R T}{-\beta n F}
\end{gathered}
$$

where $R$ represents the gas constant, $T$ is the absolute temperature, and $n$ is the electron number transferred during the corrosion reaction.

The corrosion rate, $r$, defined as the depth of corrosion penetration per time, was calculated with $j_{\text {corr }}$ following Equation (6), assuming uniform corrosion.

$$
r=\frac{j_{\text {corr } M}}{n F \rho}
$$

where $M$ is the molecular mass of the corroding metal, $F$ is the Faraday constant, and $\rho$ is the metal density. $n$ was assumed to be 2 for the corrosion reaction of Fe. 


\section{Results and Discussion}

\subsection{Chemical species in the test solutions}

The chemical species in the test solutions at $85{ }^{\circ} \mathrm{C}$ were calculated with commercial modeling software [31]. The concentrations of $\mathrm{CO}_{2}(\mathrm{aq}), \mathrm{HCO}_{3}{ }^{-}(\mathrm{aq})$, and $\mathrm{H}_{2} \mathrm{~S}(\mathrm{aq})$ decreased as the $\mathrm{pH}$ increased, whereas the concentrations of $\mathrm{CO}_{3}{ }^{2-}(\mathrm{aq})$ and $\mathrm{S}^{2-}(\mathrm{aq})$ increased. $\mathrm{HS}^{-}$(aq) was calculated to be the primary sulfide species, and its concentration was similar among the three solutions for each $p_{\mathrm{H} 2 \mathrm{~S}}$. When $p_{\mathrm{H} 2 \mathrm{~S}}$ increased, the concentrations of sulfide species increased by the corresponding order of magnitude. The carbonate species did not change significantly at different $p_{\mathrm{H} 2 \mathrm{~S}}$ due to relatively low total $\mathrm{H}_{2} \mathrm{~S}$ concentrations.

It has been proposed that $\mathrm{OH}^{-}(\mathrm{aq}), \mathrm{HCO}_{3}^{-}(\mathrm{aq})$, and $\mathrm{HS}^{-}(\mathrm{aq})$ could react with $\mathrm{Fe}$ for anodic reactions $[3-5,28]$. Their concentrations are given and compared in Table 3. It can be seen that the dominant reactive anions changed from $\mathrm{HCO}_{3}{ }^{-}(\mathrm{aq})$ to $\mathrm{OH}^{-}(\mathrm{aq})$ as the $\mathrm{pH}$ increased from Solution \#1 to \#3, while the concentration of $\mathrm{HS}^{-}$(aq) was similar among the three solutions. In Solution \#2, the dominant reactive anions were the most diverse. For example, there were at least two dominant reactive anions, $\mathrm{HCO}_{3}{ }^{-}(\mathrm{aq})$ and $\mathrm{OH}^{-}(\mathrm{aq})$, whose concentrations were in the same order of magnitude in Solution \#2. The $\mathrm{HS}^{-}(\mathrm{aq})$ concentration became higher with the increase of $p_{\mathrm{H} 2 \mathrm{~S}}$. The ratio of $\mathrm{HS}^{-}(\mathrm{aq})$ concentration to the total concentration of $\mathrm{OH}^{-}(\mathrm{aq})+\mathrm{HCO}_{3}^{-}(\mathrm{aq})+\mathrm{HS}^{-}(\mathrm{aq})$ was the largest in Solution \#2. The concentrations could impact the surface coverage of ions on the steel surface and therefore the reaction paths.

\section{Table 3}

The concentrations ( $\mathrm{mol} \mathrm{kg}^{-1}$ ) of reactive anions calculated with commercial modeling software [31]. 


\begin{tabular}{cccccc}
\hline$p_{\mathrm{H} 2 \mathrm{~S}}$ & Solution & $\mathrm{OH}^{-}(\mathrm{aq})$ & $\mathrm{HCO}_{3}^{-}(\mathrm{aq})$ & $\mathrm{HS}^{-}(\mathrm{aq})$ & $\mathrm{HS}(\mathrm{aq})$ ratio \\
\hline \multirow{2}{*}{$0 \mathrm{kPa}$} & $\# 1$ & $4.20 \times 10^{-5}$ & $4.57 \times 10^{-1}$ & 0 & 0 \\
& $\# 3$ & $2.35 \times 10^{-2}$ & $2.43 \times 10^{-2}$ & 0 & 0 \\
\hline & $\# 1$ & $4.18 \times 10^{-5}$ & $4.57 \times 10^{-1}$ & $2.48 \times 10^{-4}$ & 0.00054 \\
$0.83 \mathrm{kPa}$ & $\# 2$ & $2.33 \times 10^{-2}$ & $2.44 \times 10^{-2}$ & $2.62 \times 10^{-4}$ & 0.0055 \\
& $\# 3$ & $9.63 \times 10^{-1}$ & $5.17 \times 10^{-4}$ & $2.54 \times 10^{-4}$ & 0.00026 \\
\hline \multirow{3}{*}{$8.3 \mathrm{kPa}$} & $\# 2$ & $2.22 \times 10^{-2}$ & $2.56 \times 10^{-2}$ & $2.62 \times 10^{-3}$ & 0.052 \\
& $\# 1$ & $4.01 \times 10^{-5}$ & $4.56 \times 10^{-1}$ & $2.48 \times 10^{-3}$ & 0.0054 \\
& $\# 3$ & $9.60 \times 10^{-1}$ & $5.17 \times 10^{-4}$ & $2.54 \times 10^{-3}$ & 0.0026 \\
\hline $69 \mathrm{kPa}$ & $\# 2$ & $1.49 \times 10^{-2}$ & $3.73 \times 10^{-2}$ & $2.19 \times 10^{-2}$ & 0.29 \\
& $\# 3$ & $9.41 \times 10^{-1}$ & $5.22 \times 10^{-4}$ & $2.12 \times 10^{-2}$ & 0.022 \\
\hline & & $2.74 \times 10^{-5}$ & $4.52 \times 10^{-1}$ & $2.01 \times 10^{-2}$ & 0.043 \\
& & & & 0 \\
\hline
\end{tabular}

\subsection{Corrosion potential $\left(E_{\mathrm{corr}}\right)$}

The anodic reaction for corrosion of carbon steel is mainly oxidation of $\mathrm{Fe}(\mathrm{s})$ to $\mathrm{Fe}^{2+}(\mathrm{aq})$, the reduction reaction of which is shown in Equation (7). The cathodic reaction in acidic solutions is the reduction of $\mathrm{H}^{+}(\mathrm{aq})$ to hydrogen. In the anaerobic alkaline conditions, the $\mathrm{H}^{+}(\mathrm{aq})$ concentration was quite low, and the hydrogen sources for cathodic reactions could be $\mathrm{H}_{2} \mathrm{~S}(\mathrm{aq}), \mathrm{H}_{2} \mathrm{O}(\mathrm{l}), \mathrm{H}_{2} \mathrm{CO}_{3}(\mathrm{aq})$, and other hydrogen-containing species. Equations (8) - (10) give the examples of $\mathrm{H}^{+}(\mathrm{aq}), \mathrm{H}_{2} \mathrm{O}(\mathrm{l})$, and $\mathrm{H}_{2} \mathrm{~S}(\mathrm{aq})$ as the hydrogen sources for the HER. The standard electrode potential $E^{0}$ at $85{ }^{\circ} \mathrm{C}$ was calculated using the Gibbs free energy values from HCh chemical simulation software and OLI Analyzer software [31,34]. The Nernst equations for Reactions (7) - (10) are given in Equations (11) (14). Both the anodic and cathodic reactions are written as reduction reactions. The activity, $a$, was used 
to account for concentration effects for the ionic species in non-ideal solutions. $p_{\mathrm{H} 2(\mathrm{~g})}$ represents the partial pressure of $\mathrm{H}_{2}(\mathrm{~g})$ and the fugacity coefficient was assumed to be unity.

$$
\begin{array}{r}
\mathrm{Fe}^{2+}(\mathrm{aq})+2 \mathrm{e}^{-}=\mathrm{Fe}(\mathrm{s}), E^{0}=-0.473 \mathrm{~V} \text { vs SHE, } 85^{\circ} \mathrm{C} \\
2 \mathrm{H}^{+}(\mathrm{aq})+2 \mathrm{e}^{-}=\mathrm{H}_{2}(\mathrm{~g}), E^{0}=0 \mathrm{~V} \text { vs SHE, } 85^{\circ} \mathrm{C} \\
2 \mathrm{H}_{2} \mathrm{O}(\mathrm{l})+2 \mathrm{e}^{-}=\mathrm{H}_{2}(\mathrm{~g})+2 \mathrm{OH}^{-}(\mathrm{aq}), E^{0}=-0.890 \mathrm{~V} \text { vs SHE, } 85^{\circ} \mathrm{C} \\
2 \mathrm{H}_{2} \mathrm{~S}(\mathrm{aq})+2 \mathrm{e}^{-}=\mathrm{H}_{2}(\mathrm{~g})+2 \mathrm{HS}^{-}(\mathrm{aq}), E^{0}=-0.463 \mathrm{~V} \text { vs SHE, } 85{ }^{\circ} \mathrm{C} \\
E_{\mathrm{Fe}^{2+} \mid \mathrm{Fe}}=E_{\mathrm{Fe}^{2+} \mid \mathrm{Fe}}^{0}+\frac{R T}{2 F} \ln a_{\mathrm{Fe}^{2+}(\mathrm{aq})} \\
E_{\mathrm{H}^{+} \mid \mathrm{H}_{2}}=E_{\mathrm{H}^{+} \mid \mathrm{H}_{2}}^{0}+\frac{R T}{2 F} \ln \frac{a_{\mathrm{H}^{+}(\mathrm{aq})}^{2}}{p_{\mathrm{H}_{2}(\mathrm{~g})}} \\
E_{\mathrm{H}_{2} \mathrm{O} \mid \mathrm{H}_{2}}=E_{\mathrm{H}_{2} \mathrm{O} \mid \mathrm{H}_{2}}^{0}+\frac{R T}{2 F} \ln \frac{a_{\mathrm{H}_{2} \mathrm{O}(\mathrm{l})}^{2}}{a_{\mathrm{OH}^{-}(\mathrm{aq})} p_{\mathrm{H}_{2}(\mathrm{~g})}} \\
E_{\mathrm{H}_{2} \mathrm{~S} \mid \mathrm{H}_{2}}=E_{\mathrm{H}_{2} \mathrm{~S} \mid \mathrm{H}_{2}}^{0}+\frac{R T}{2 F} \ln \frac{a_{\mathrm{H}_{2} \mathrm{~S}(\mathrm{aq})}^{2}}{a_{\mathrm{HS}^{-}(\mathrm{aq})} p_{\mathrm{H}_{2}(\mathrm{~g})}}
\end{array}
$$

The working electrode potential was measured with respect to the $\mathrm{Ag} / \mathrm{AgCl}$ reference electrode at temperature and was converted to the SHE scale at $85^{\circ} \mathrm{C} . E_{\text {corr }}$ generally approached a steady state by 60 hours, and the values after 60 hours are listed in Table $4 . E_{\text {corr }}$ became more negative as the $\mathrm{pH}$ increased from Solution \#1 to \#3, which can be easily explained according to Equations (12) and (13). $E_{\text {corr }}$ was generally more negative with $\mathrm{H}_{2} \mathrm{~S}$ probably because of Reaction (10).

\section{Table 4}

$E_{\text {corr }}(\mathrm{vs}$ SHE / V) of UD-165 after 60 hours.

$\begin{array}{lllll}p_{\mathrm{H} 2 \mathrm{~S}} / \mathrm{kPa} & 0 & 0.83 & 8.3 & 69\end{array}$




\begin{tabular}{ccccc} 
Solution \#1 & -0.282 & -0.663 & -0.376 & -0.451 \\
Solution \#2 & -0.366 & -0.730 & -0.452 & -0.502 \\
Solution \#3 & -0.418 & - & -0.495 & -0.612 \\
\hline
\end{tabular}

\subsection{Polarization resistance and corrosion rate}

$R_{\text {pol }}$ generally increased over time and approached a steady state by 60 hours [25]. Experimental $R_{\text {pol }}$ after 60 hours in all the conditions are shown in Fig. 2, and the corresponding CR are shown in Fig. 3. At least three data points were taken after 60 hours to calculate the average and the standard deviation values. In the conditions without $\mathrm{H}_{2} \mathrm{~S}$, the $\mathrm{CR}$ decreased as the $\mathrm{pH}$ increased, which was attributed to the lack of a hydrogen source for cathodic reaction and the formation of more protective corrosion product films. For $p_{\mathrm{H} 2 \mathrm{~S}}=0.83 \mathrm{kPa}$ and $69 \mathrm{kPa}$, the $\mathrm{CR}$ was the highest at $\mathrm{pH}=10.7$ and the lowest at $\mathrm{pH}=12.4$. The highest $\mathrm{CR}$ correlated with the highest $\mathrm{HS}^{-}(\mathrm{aq})$ ratio and the most diverse dominant reactive ions in Solution \#2. The diversity of reactive ions could lead to non-homogeneous corrosion product layers where cracking tended to occur, resulting in localized corrosion. At $p_{\mathrm{H} 2 \mathrm{~S}}=8.3 \mathrm{kPa}$, the CR trend with $\mathrm{pH}$ was different and the lowest value appeared at $\mathrm{pH} 10.7$, which could be related to a more protective corrosion product layer on the steel surface where localized corrosion had not manifested significantly.

The addition of low $p_{\mathrm{H} 2 \mathrm{~S}}(0.83 \mathrm{kPa})$ decreased the $\mathrm{CR}$ at $\mathrm{pH} 7.9$ and 12.4 due to the formation of a thin protective sulfide film $[6,35]$. Compared with the conditions without $\mathrm{H}_{2} \mathrm{~S}$, the addition of higher $p_{\mathrm{H} 2 \mathrm{~S}}(8.3$ and $69 \mathrm{kPa})$ generally increased $\mathrm{CR}$ in the three solutions except for $p_{\mathrm{H} 2 \mathrm{~S}}=69 \mathrm{kPa}$ in Solution \#1. Higher $p_{\mathrm{H} 2 \mathrm{~S}}$ provided a further source of hydrogen for the HER following Reaction (10), and $\mathrm{H}_{2} \mathrm{~S}$ was reported to facilitate pitting corrosion and, therefore, increase the CR [14]. Higher $\mathrm{HS}^{-}$(aq) concentration could have accelerated the Fe dissolution reaction. At higher $p_{\mathrm{H} 2 \mathrm{~S}}$, the corrosion product layers could have become less protective as the layers grew thicker, because cracking could occur to 
relieve the intrinsic stress in the inner layer, leading to a loose and porous outer layer [15]. At pH 10.7, the low $p_{\mathrm{H} 2 \mathrm{~S}}(0.83 \mathrm{kPa})$ also increased $\mathrm{CR}$ compared with the condition without $\mathrm{H}_{2} \mathrm{~S}$, indicating that the corrosion product layers might have grown too thick to be as protective as a thin film.

To summarize, there were two competing effects of $\mathrm{H}_{2} \mathrm{~S}$ on corrosion rate observed in alkaline brines at $85{ }^{\circ} \mathrm{C}$ : 1) an accelerating effect due to $\mathrm{H}_{2} \mathrm{~S}(\mathrm{aq})$ and $\mathrm{HS}^{-}$(aq) facilitating the Faradaic electrochemical reactions and localized corrosion; and 2) an inhibiting effect due to the protectiveness of sulfide corrosion products. The combination of these two effects determined the overall influence of $\mathrm{H}_{2} \mathrm{~S}$ on corrosion.

\subsection{The effect of stir rate}

Fig. 4 shows the EIS Nyquist plots at different stir rates in Solution \#2 at $p_{\mathrm{H} 2 \mathrm{~S}}=69 \mathrm{kPa}$, and the patterns were almost the same when changing the stir rate. Similar behavior was found in the other conditions, except that some change was observed over time for tests where the system had not quite reached a steady state. This result indicated that the electrochemical impedance was not changed by changing the hydrodynamics in the bulk solution, and mass transport (diffusion or convection) in the bulk solution did not affect the rate determining step for the overall corrosion.

\subsection{Linear sweep voltammetry results}

The LSV plots at $p_{\mathrm{H} 2 \mathrm{~S}}=0 \mathrm{kPa}$ and $69 \mathrm{kPa}$ are shown in Fig. 5 and Fig. 6, respectively. Based on the fact that the anodic and cathodic LSV plots were swept in opposite directions and the dips of these LSV plots shifted toward opposite directions, the shift was possibly due to the capacitance effect in the corrosion system such as the electrical double layer capacitance at the steel/solution interface. The Tafel slopes obtained from the LSV plots are listed in Table 5. 
At $p_{\mathrm{H} 2 \mathrm{~S}}=0 \mathrm{kPa}$, an anodic limiting current was observed in each of the three solutions. At $p_{\mathrm{H} 2 \mathrm{~S}}=69$

$\mathrm{kPa}$, the anodic current densities increased, and there were no obvious anodic limiting current densities. This accelerating effect of $\mathrm{H}_{2} \mathrm{~S}$ could be attributed to the additional anodic reaction path provided by HS (aq).

\section{Table 5}

The Tafel slopes in the three solutions at $p_{\mathrm{H} 2 \mathrm{~S}}=0 \mathrm{kPa}$ (I) and $69 \mathrm{kPa}$ (II) at $85^{\circ} \mathrm{C}$ after 60 hours.

\begin{tabular}{ccccccc}
\hline Tafel slope / V & I-\#1 & I-\#2 & I-\#3 & II-\#1 & II-\#2 & II-\#3 \\
\hline$b_{\text {a }}$ & limiting & limiting & limiting & 0.115 & $0.069,0.132$ & 0.062 \\
$b_{\mathrm{c}}$ & -0.290 & -0.498 & -0.372 & limiting & -0.500 & -0.360 \\
\hline
\end{tabular}

According to Equation (4), the $b_{\mathrm{a}}$ values were calculated to be $0.142 \mathrm{~V}$ and $0.071 \mathrm{~V}$ at $85^{\circ} \mathrm{C}$ for a one-electron mechanism $(n=1)$ and a two-electron mechanism $(n=2)$, respectively. Bockris et al. [5] proposed a mechanism for Fe dissolution involving the oxidation of an intermediate with $\mathrm{OH}^{-}(\mathrm{aq})$ as the rate determining step (RDS), as shown in Reactions (15) to (18). The $b_{\mathrm{a}}$ for the Bockris mechanism was calculated to be $0.047 \mathrm{~V}$ according to Equation (19), assuming the symmetry factor $\beta$ to be 0.5 .

For $p_{\mathrm{H} 2 \mathrm{~S}}=69 \mathrm{kPa}$ in Table $5, b_{\mathrm{a}}$ in Solution \#1 was between the one-electron mechanism and the two-electron mechanism, and $b_{\mathrm{a}}$ in Solution \#3 was between the two-electron mechanism and the Bockris mechanism. $b_{\mathrm{a}}$ in Solution \#2 was close to the two-electron mechanism at small anodic polarization and the one-electron mechanism at larger anodic polarization. The Tafel slope reflected a comprehensive effect from all of the reactants including $\mathrm{OH}^{-}(\mathrm{aq}), \mathrm{HCO}_{3}^{-}(\mathrm{aq})$, and $\mathrm{HS}^{-}(\mathrm{aq})$. According to Table 3, the $\mathrm{HS}^{-}(\mathrm{aq})$ ratio in Solution \#2 was the largest (29\%) where the $\mathrm{HS}^{-}(\mathrm{aq})$ reaction path probably became more pronounced. Therefore, it was proposed that the $\mathrm{HS}^{-}(\mathrm{aq})$ reaction path might have involved two electrons transferring simultaneously as the RDS. Considering that the dominant reactive 
ions changed from $\mathrm{HCO}_{3}{ }^{-}(\mathrm{aq})$ to $\mathrm{OH}^{-}(\mathrm{aq})$ as the $\mathrm{pH}$ increased from Solution \#1 to \#3, the $\mathrm{HCO}_{3}{ }^{-}(\mathrm{aq})$ reaction path probably followed the one-electron mechanism, and the $\mathrm{OH}^{-}(\mathrm{aq})$ reaction path followed the Bockris mechanism. The chemisorbed $\operatorname{HS}^{-}(\mathrm{aq})$ could occupy comparatively more active sites on the steel surface [36], which could explain the interference from the two-electron mechanism of $\mathrm{HS}^{-}$(aq) in the $b_{\mathrm{a}}$ values for Solutions \#1 and \#3. Reactions and Equations (20) to (28) could be plausible steps for the one-electron and the two-electron mechanisms, modified from the mechanisms proposed by other researchers [3-5,37].

The Bockris mechanism for $\mathrm{OH}^{-}(\mathrm{aq})$

$$
\begin{array}{ll}
\text { Step I: } & \mathrm{Fe}(\mathrm{s})+\mathrm{OH}^{-}(\mathrm{aq}) \leftrightarrow \mathrm{FeOH}(\mathrm{ad})+\mathrm{e}^{-} \\
\text {Step II (RDS): } & \mathrm{FeOH}(\mathrm{ad}) \rightarrow \mathrm{FeOH}^{+}(\mathrm{ad})+\mathrm{e}^{-} \\
\text {Step III: } & \mathrm{FeOH}^{+}(\mathrm{ad})+\mathrm{H}_{3} \mathrm{O}^{+}(\mathrm{aq}) \leftrightarrow \mathrm{Fe}^{2+}(\mathrm{aq})+2 \mathrm{H}_{2} \mathrm{O}(\mathrm{l}) \\
& \mathrm{FeOH}^{+}(\mathrm{ad})+\mathrm{OH}^{-}(\mathrm{aq}) \leftrightarrow \mathrm{Fe}(\mathrm{OH})_{2}(\mathrm{~s}) \\
& \\
& b_{a}=\frac{2.303 R T}{(1+\beta) F}
\end{array}
$$

One-electron mechanism for $\mathrm{HCO}_{3}{ }^{-}(\mathrm{aq})$

$$
\begin{array}{ll}
\text { Step I (RDS): } & \mathrm{Fe}(\mathrm{s})+\mathrm{HCO}_{3}^{-}(\mathrm{aq}) \rightarrow \mathrm{FeHCO}_{3}(\mathrm{ad})+\mathrm{e}^{-} \\
\text {Step II: } & \mathrm{FeHCO}_{3}(\mathrm{ad}) \leftrightarrow \mathrm{FeHCO}_{3}{ }^{+}(\mathrm{ad})+\mathrm{e}^{-} \\
\text {Step III: } & \mathrm{FeHCO}_{3}^{+}(\mathrm{ad}) \leftrightarrow \mathrm{Fe}^{2+}(\mathrm{aq})+\mathrm{HCO}_{3}{ }^{-}(\mathrm{aq}) \\
& \mathrm{FeHCO}_{3}^{+}(\mathrm{ad})+\mathrm{OH}^{-}(\mathrm{aq}) \leftrightarrow \mathrm{FeCO}_{3}(\mathrm{~s})+\mathrm{H}_{2} \mathrm{O}(\mathrm{l}) \\
& \\
& b_{a}=\frac{2.303 R T}{(1-\beta) F}
\end{array}
$$

Two-electron mechanism for $\mathrm{HS}^{-}(\mathrm{aq})$

$$
\text { Step I (RDS): } \quad \mathrm{Fe}(\mathrm{s})+\operatorname{HS}^{-}(\mathrm{aq}) \rightarrow \mathrm{FeHS}^{+}(\mathrm{ad})+2 \mathrm{e}^{-}
$$




$$
\begin{gathered}
\text { Step II: } \quad \operatorname{FeHS}^{+}(\mathrm{ad}) \leftrightarrow \mathrm{Fe}^{2+}(\mathrm{aq})+\mathrm{HS}^{-}(\mathrm{aq}) \\
\text { or } \quad \mathrm{FeHS}^{+}(\mathrm{ad})+\mathrm{OH}^{-}(\mathrm{aq}) \leftrightarrow \mathrm{FeS}(\mathrm{s})+\mathrm{H}_{2} \mathrm{O}(\mathrm{l}) \\
b_{a}=\frac{2.303 R T}{2(1-\beta) F}
\end{gathered}
$$

According to the cathodic LSV plots in Fig. 5 and Fig. 6, the cathodic current density decreased with increasing $\mathrm{pH}$ and increased in the presence of $\mathrm{H}_{2} \mathrm{~S}$. A cathodic limiting current was only observed in Solution $\# 1$ at $p_{\mathrm{H} 2 \mathrm{~S}}=69 \mathrm{kPa}$; however, here the cathodic current density was the highest. In Solution \#1 at $p_{\mathrm{H} 2 \mathrm{~S}}=69 \mathrm{kPa}, \mathrm{H}_{2} \mathrm{~S}(\mathrm{aq})$ was the most abundant and could have served as the main reactant for the HER. The cathodic limiting current was likely due to mass transport or a chemical step related to $\mathrm{H}_{2} \mathrm{~S}(\mathrm{aq})$. With further negative polarization, $\mathrm{H}_{2} \mathrm{O}(1)$ started to get reduced as an additional hydrogen source, and the cathodic limiting current disappeared. In the other conditions, $\mathrm{H}_{2} \mathrm{O}(\mathrm{l})$ could be the main reactant for the cathodic reaction for lack of $\mathrm{H}^{+}(\mathrm{aq})$ and $\mathrm{H}_{2} \mathrm{~S}(\mathrm{aq})$, and, therefore, the cathodic current density was comparatively low but was not limited over the cathodic polarization. A similar phenomenon was reported when the effect of $\mathrm{pH}$ on the cathodic polarization was studied by Stern [38]. The VolmerHeyrovsky (V-H) and Volmer-Tafel (V-T) mechanisms are commonly accepted for the HER, and these two mechanisms are given in the Appendix [37]. The cathodic Tafel slopes at $85^{\circ} \mathrm{C}$ were calculated to be $-0.142 \mathrm{~V}$ and $-0.036 \mathrm{~V}$ for the $\mathrm{V}-\mathrm{H}$ and $\mathrm{V}-\mathrm{T}$ mechanisms, respectively, assuming the symmetry factor $\beta$ to be 0.5 . The measured $b_{\mathrm{c}}$ values in Table 5 were much larger, indicating that the reaction mechanisms of $\mathrm{H}_{2} \mathrm{O}(\mathrm{l})$ and other hydrogen sources were different from the $\mathrm{V}-\mathrm{H}$ and $\mathrm{V}-\mathrm{T}$ mechanisms.

\subsection{Electrochemical impedance spectroscopy results}

The EIS results of UD-165 after 60 hours are shown in Fig. 7. For both $p_{\mathrm{H} 2 \mathrm{~S}}=0$ and $69 \mathrm{kPa}$, the phase angles showed one broad time constant in Solutions \#1 and \#3 and two separated time constants in 
Solution \#2, which could indicate different mechanisms. The two separtated time constants could be attributed to the diversity of dominant reactive ions and the highest $\mathrm{HS}^{-}(\mathrm{aq})$ ratio in Solution \#2. The EIS data in Solutions \#1 and \#3 were fitted using the equivalent circuit (a) in Fig. 8, which consisted of a solution resistance $\left(R_{\mathrm{sol}}\right)$ in series with a parallel combination of a constant phase element $(\mathrm{CPE})$ and a resistor. As a substitute for the capacitor in the Randles circuit, a CPE was used to represent the nonideality of the double layer capacitance.

The impedance of a CPE, $Z_{\mathrm{Q}}$, is defined in Equation (29) [4].

$$
Z_{\mathrm{Q}}=\left(Y_{0}\right)^{-1}(i \omega)^{-p}
$$

where $Y_{0}$ is the admittance modulus, $i$ the imaginary unit, $\omega$ the angular frequency, and $p$ the exponent within 0 to 1 . When $p=1$, a CPE is identical to an ideal capacitor; when $p=0$, a CPE behaves as a resistor; and when $p=0.5$, a CPE can serve as an infinite-length Warburg element representing diffusion of the charge carriers.

In Circuit (a), $R 1$ can be seen as the polarization resistance for the corrosion process, and CPE1 represents the non-ideal double layer capacitor at the steel/solution interface. The change of stir rate showed little effect on the corrosion behavior as discussed in Section 3.4; therefore, the Warburg diffusion element was not included in Circuit (a). The fitting results are listed in Table 6. The CPE1-p values were mostly between 0.8 and 1 , which was the usual range due to the non-ideality of the double layer capacitance at the steel/solution interface $[4,39]$. Compared with the $R_{\text {pol }}$ values from LPR, which are also given in Table 6 , the $R 1$ values were on the same order of magnitude with $R_{\text {pol }}$ from LPR, although they tended to be larger. $R 1$ increased at the higher $\mathrm{pH}$ in Solution \#3 and decreased in the presence of $\mathrm{H}_{2} \mathrm{~S}$, which agreed with the $R_{\text {pol }}$ results.

Circuit (b) in Fig. 8 was used to fit the EIS data from Solution \#2. There was a second parallel combination of CPE2 and $R 2$ in series with $R 1$. This circuit has been reported to represent multiple 
phenomena such as corrosion with a porous film, passivation, and adsorption/desorption [20,39-41]. For lack of data at low frequency, $R 2$ in Solution \#2 were computed to be very large, especially at $p_{\mathrm{H} 2 \mathrm{~S}}=69$

$\mathrm{kPa}$. In Solution $\# 2, R_{\mathrm{pol}}$ from LPR was one order of magnitude larger than $R 1$ and much smaller than $R 2$. LPR was measured at a sweep rate $\left(1 \mathrm{mV} \mathrm{s}^{-1}\right)$ which would correspond to a frequency between where $R 1$ and $R 2$ were observed in EIS. Regardless of $R 2, R 1$ decreased in the presence of $\mathrm{H}_{2} \mathrm{~S}$.

\section{Table 6}

EIS fitting results in the three solutions at $p_{\mathrm{H} 2 \mathrm{~S}}=0 \mathrm{kPa}$ (I) and $69 \mathrm{kPa}$ (II) at $85^{\circ} \mathrm{C}$.

\begin{tabular}{|c|c|c|c|c|c|c|c|}
\hline Element & Units & I-\#1 & I-\#2 & I-\#3 & II-\#1 & II-\#2 & II-\#3 \\
\hline$R_{\mathrm{sol}}$ & $\Omega \mathrm{cm}^{2}$ & 3.52 & 2.98 & 2.69 & 3.72 & 3.17 & 2.83 \\
\hline CPE1- $Y_{0}$ & $\Omega^{-1} \mathrm{~cm}^{-2} \mathrm{~s}^{p}$ & $1.14 \times 10^{-2}$ & $2.39 \times 10^{-4}$ & $1.44 \times 10^{-3}$ & $7.70 \times 10^{-3}$ & $3.64 \times 10^{-3}$ & $3.93 \times 10^{-3}$ \\
\hline CPE1- $p$ & $0-1$ & 0.67 & 0.79 & 0.87 & 0.92 & 0.78 & 0.94 \\
\hline$R 1$ & $\mathrm{k} \Omega \mathrm{cm}^{2}$ & 8.62 & 1.64 & 47.75 & 8.10 & 0.16 & 12.06 \\
\hline CPE2- $Y_{0}$ & $\Omega^{-1} \mathrm{~cm}^{-2} \mathrm{~s}^{p}$ & - & $1.90 \times 10^{-3}$ & - & - & $9.72 \times 10^{-3}$ & - \\
\hline CPE2- $p$ & $0-1$ & - & 0.82 & - & - & 0.68 & - \\
\hline$R 2$ & $\mathrm{k} \Omega \mathrm{cm}^{2}$ & - & 122.88 & - & - & $8.75 \times 10^{16}$ & - \\
\hline$R_{\mathrm{pol}}-\mathrm{LPR}$ & $\mathrm{k} \Omega \mathrm{cm}^{2}$ & 1.45 & 16.30 & 24.16 & 5.08 & 1.14 & 9.41 \\
\hline
\end{tabular}


The Pourbaix diagrams at $85{ }^{\circ} \mathrm{C}$ were generated with commercial modeling software [42]. Fig. 9 and Fig. 10 show the diagrams for Solution $\# 2$ at $p_{\mathrm{H} 2 \mathrm{~S}}=0$ and $69 \mathrm{kPa}$, respectively, and the diagrams for Solutions \#1 and \#3 were similar to Solution \#2. There were some curved equilibrium boundaries in Fig. 9 and Fig. 10 because the modeling took into account the non-ideality and speciation in real solutions, which made the stability diagrams more realistic than classical Pourbaix diagrams. For example, in Fig. 9, the curved boundaries between $\mathrm{Fe}(\mathrm{s})$ and $\mathrm{FeH}\left(\mathrm{CO}_{3}\right)_{2}{ }^{-}(\mathrm{aq})$ and between $\mathrm{FeH}\left(\mathrm{CO}_{3}\right)_{2}{ }^{-}(\mathrm{aq})$ and $\mathrm{Fe}_{2} \mathrm{O}_{3}(\mathrm{~s})$ were due to the non-ideality effect (i.e., activity coefficients in real solutions) and the activities of participating species like $\mathrm{CO}_{3}{ }^{2-}(\mathrm{aq})$ as a function of $\mathrm{pH}$. At $p_{\mathrm{H} 2 \mathrm{~S}}=0 \mathrm{kPa}$, the thermodynamically predominant species changed from $\mathrm{FeH}\left(\mathrm{CO}_{3}\right)_{2}{ }^{-}(\mathrm{aq})$ to $\mathrm{FeCO}_{3}(\mathrm{~s}) / \mathrm{Fe}_{3} \mathrm{O}_{4}(\mathrm{~s})$ and then to $\mathrm{HFeO}_{2}{ }^{-}$ (aq)/ $/ \mathrm{Fe}_{3} \mathrm{O}_{4}$ (s) as the $\mathrm{pH}$ increased from 7.9 to 10.7 and then to 12.4. There was a trend of changing from iron carbonate to iron oxides as the $\mathrm{pH}$ increased. At $p_{\mathrm{H} 2 \mathrm{~S}}=69 \mathrm{kPa}$, the thermodynamically predominant species changed from $\mathrm{FeS}(\mathrm{s}) / \mathrm{FeS}_{2}(\mathrm{~s}) / \mathrm{FeH}\left(\mathrm{CO}_{3}\right)_{2}{ }^{-}(\mathrm{aq})$ to $\mathrm{FeS}(\mathrm{s}) / \mathrm{FeS}_{2}(\mathrm{~s}) / \mathrm{Fe}_{3} \mathrm{O}_{4}(\mathrm{~s})$ and then to $\mathrm{FeS}(\mathrm{s}) / \mathrm{Fe}_{3} \mathrm{O}_{4}(\mathrm{~s}) / \mathrm{HFeO}_{2}{ }^{-}(\mathrm{aq})$ as the $\mathrm{pH}$ increased from 7.9 to 12.4 . When $p_{\mathrm{H} 2 \mathrm{~S}}$ increased from $0.83 \mathrm{kPa}$ to $69 \mathrm{kPa}$, the stable regions of $\mathrm{FeS}(\mathrm{s})$ and $\mathrm{FeS}_{2}(\mathrm{~s})$ expanded.

The SEM images of the UD-165 samples after the corrosion tests at $p_{\mathrm{H} 2 \mathrm{~S}}=0 \mathrm{kPa}$ and $69 \mathrm{kPa}$ are shown in Fig. 11 and Fig. 12, respectively. The EDS results of some selected locations are given in Table 7. The accelerating voltage for EDS was $7 \mathrm{kV}$, as a larger voltage was found to penetrate too deep into the substrate.

For the steel samples corroded at $p_{\mathrm{H} 2 \mathrm{~S}}=0 \mathrm{kPa}$, the corrosion products were generally a mixture of iron carbonate and oxides according to Table 7. The morphology of the steel surfaces varied in the three solutions. As shown in Fig. 11 (A), the steel sample corroded in Solution \#1 seemed to have two layers of corrosion products, an inner layer adjacent to the steel and an outer layer. The chemical composition of the cubic crystals which constituted the outer layer was very close to $\mathrm{FeCO}_{3}(\mathrm{~s})$, as in Location 1 . The corrosion products in Solution \#2 formed a thin layer on the steel surface, as shown in Fig. 11 (B). The detected chemical compositions suggested the existence of $\mathrm{FeCO}_{3}(\mathrm{~s})$ and $\mathrm{Fe}(\mathrm{s})$ on the steel surface, as 
the $\mathrm{C}: \mathrm{O}$ atomic ratio was very close to $1: 3$ and the iron content was high in some spots like Location 5.

The high iron content could be due to the stimulated signal from the steel substrate through the thin film.

The corroded surface in Solution \#3 shown in Fig. 11 (C) contained a relatively high amount of O, which might be from the iron oxides on the steel surface.

\section{Table 7}

The results of EDS chemical analyses (at\%) on the corroded UD-165 steel surfaces.

\begin{tabular}{|c|c|c|c|c|c|c|c|}
\hline Fig. & $p_{\mathrm{H} 2 \mathrm{~S}} / \mathrm{kPa}$ & $\mathrm{pH}$ & Location & $\mathrm{Fe}$ & $\mathrm{C}$ & $\mathrm{O}$ & $S$ \\
\hline \multirow{9}{*}{ Fig. 11} & \multirow{9}{*}{0} & \multirow{3}{*}{7.9} & 1 & 16 & 19 & 60 & - \\
\hline & & & 2 & 30 & 5.0 & 53 & - \\
\hline & & & 3 & 32 & 11 & 46 & - \\
\hline & & \multirow{3}{*}{10.7} & 4 & 8.2 & 13 & 45 & - \\
\hline & & & 5 & 58 & 7.6 & 23 & - \\
\hline & & & 6 & 37 & 12 & 34 & - \\
\hline & & \multirow{3}{*}{12.4} & 7 & 24 & 8.0 & 47 & - \\
\hline & & & 8 & 7.4 & 12 & 47 & - \\
\hline & & & 9 & 40 & 9.0 & 41 & - \\
\hline \multirow{9}{*}{ Fig. 12} & \multirow{9}{*}{69} & & 1 & 28 & 13 & 46 & 11 \\
\hline & & 7.7 & 2 & 31 & 9.4 & 26 & 32 \\
\hline & & & 3 & 35 & 9.4 & 24 & 32 \\
\hline & & & 4 & 60 & 10 & 23 & 4.4 \\
\hline & & 10.5 & 5 & 28 & 30 & 38 & 1.7 \\
\hline & & & 6 & 39 & - & 56 & 1.7 \\
\hline & & & 7 & 31 & 9.7 & 44 & 12 \\
\hline & & 12.4 & 8 & 30 & 14 & 41 & 13 \\
\hline & & & 9 & 30 & 16 & 44 & 7.6 \\
\hline
\end{tabular}


At $p_{\mathrm{H} 2 \mathrm{~S}}=69 \mathrm{kPa}, \mathrm{S}$ was detected on the steel surfaces, and the amounts were higher than those at $p_{\mathrm{H} 2 \mathrm{~S}}=0.83$ and $8.3 \mathrm{kPa}$. According to Table 7, the corrosion products in the three solutions contained Fe, $\mathrm{C}, \mathrm{O}$ and $\mathrm{S}$, which were probably a mixture of iron carbonate, iron sulfides, and iron oxides due to the multiple reactants. However, the morphology of the corrosion products was different in the three solutions. As shown in Fig. 12 (A), the microstructure of the corrosion products was comparatively loose in Solution \#1. As shown in Fig. 12 (B), in Solution \#2, massive corrosion products were detected along Locations 5 and 6, whereas the other areas were quite flat, suggesting that localized corrosion had taken place. This could be one of the reasons that the CR in Solution \#2 was the highest. Location 4 appeared to contain 60 at $\% \mathrm{Fe}$, indicating that it could be the active steel surface or a very thin corrosion product film. In Solution \#3, the microstructure of the corrosion products was like a honeycomb as shown in Fig. 12 (C) and (D), which could act as a barrier for the transport of reactive ions. This might be one of the reasons that $R_{\mathrm{pol}}$ was the largest in Solution \#3. Limited information was obtained from XRD because the corrosion product layers were relatively thin. Iron and siderite $\left(\mathrm{FeCO}_{3}\right)$ were detected by XRD on the steel samples corroded in Solutions \#1 and \#2 at $p_{\mathrm{H} 2 \mathrm{~S}}=69 \mathrm{kPa}$, and a small peak of Fe(II) hydroxide was detected in Solution \#2. However, no significant signals from iron sulfides were collected, which could be due to the lack of a significant amount of crystalline iron sulfides on the steel surfaces.

Fig. 13 shows the EDS mapping result on the cross-section of UD-165 corroded in Solution \#1 at $p_{\mathrm{H} 2 \mathrm{~S}}=0.83 \mathrm{kPa}$ and $85^{\circ} \mathrm{C}$. Fig. 14 shows the result from EDS line scan analysis on the cross-section which is also marked in Fig. 13. It can be seen that a thin film of corrosion products formed on the steel surface and the thickness was around 2 to $4 \mu \mathrm{m}$. The uneven thickness of the film suggested that localized corrosion occurred on the steel surface. The chemical composition indicated that the film mainly consisted of Fe, S, C, and O. Sulfur was mostly detected in the inner layer, which could be due to the specific adsorption of $\mathrm{HS}^{-}(\mathrm{aq})$ or the fast kinetics of mackinawite formation $[15,36,43]$. The surface coverages of $\mathrm{OH}^{-}(\mathrm{aq}), \mathrm{HCO}_{3}{ }^{-}(\mathrm{aq})$, and $\mathrm{HS}^{-}(\mathrm{aq})$ were influenced by their concentrations and the features 
such as the ion size and specific adsorption. In Solution \#2, the highest $\mathrm{HS}^{-}(\mathrm{aq})$ ratio and the specific adsorption could make the $\mathrm{HS}^{-}(\mathrm{aq})$ reaction path more prominent, resulting in the highest CR.

\section{Conclusions}

Electrochemical corrosion of UD-165 was investigated at $\mathrm{pH} 7.9,10.7$, and 12.4 with four different $p_{\mathrm{H} 2 \mathrm{~S}}$ at $85^{\circ} \mathrm{C}$. The conclusions are:

(1) Although the CR generally decreased as the $\mathrm{pH}$ increased, the CR increased in Solution \#2 with $\mathrm{pH}$ 10.7 at $p_{\mathrm{H} 2 \mathrm{~S}}=0.83 \mathrm{kPa}$ and $69 \mathrm{kPa}$. This correlated with the highest $\mathrm{HS}^{-}(\mathrm{aq})$ ratio in Solution \#2, which could make the $\mathrm{HS}^{-}(\mathrm{aq})$ reaction path more prominent along with the specific adsorption of $\mathrm{HS}^{-}(\mathrm{aq})$. (2) Compared with the conditions without $\mathrm{H}_{2} \mathrm{~S}$, the addition of low $p_{\mathrm{H} 2 \mathrm{~S}}(0.83 \mathrm{kPa})$ decreased the $\mathrm{CR}$ at $\mathrm{pH} 7.9$ and 12.4 , and the addition of higher $p_{\mathrm{H} 2 \mathrm{~S}}(8.3$ and $69 \mathrm{kPa})$ generally increased the CR. There were two competing effects of $\mathrm{H}_{2} \mathrm{~S}$ on corrosion rate observed in alkaline brines: 1) an accelerating effect due to $\mathrm{H}_{2} \mathrm{~S}(\mathrm{aq})$ and $\mathrm{HS}^{-}(\mathrm{aq})$ facilitating the Faradaic electrochemical reactions and localized corrosion; and 2) an inhibiting effect due to the protectiveness of sulfide corrosion products. The combination of these two effects determined the overall influence of $\mathrm{H}_{2} \mathrm{~S}$ on corrosion.

(3) Considering $\mathrm{HCO}_{3}{ }^{-}(\mathrm{aq}), \mathrm{OH}^{-}(\mathrm{aq})$, and $\mathrm{HS}^{-}(\mathrm{aq})$ as the reactive ions for anodic reactions, the anodic Tafel slope reflected a comprehensive effect from all the reaction paths. Based on the correlation between the LSV results and the dominant reactive ions, it was proposed that the $\operatorname{HS}^{-}(\mathrm{aq})$ reaction path might involve two electrons transferring simultaneously as the $\mathrm{RDS}$, and the $\mathrm{HCO}_{3}{ }^{-}(\mathrm{aq})$ reaction path probably followed the one-electron mechanism, and the $\mathrm{OH}^{-}(\mathrm{aq})$ reaction path followed the Bockris mechanism.

(4) The corrosion products showed a trend of changing from iron carbonate and sulfides to iron oxides as the $\mathrm{pH}$ increased from 7.9 to 12.4 , according to the Pourbaix diagrams and the surface analysis. This was consistent with the dominant reactive ions changing from $\mathrm{HCO}_{3}{ }^{-}(\mathrm{aq})$ to $\mathrm{OH}^{-}(\mathrm{aq})$ as the $\mathrm{pH}$ increased. 
(5) Sulfur was mostly detected in the inner layer of corrosion products on the steel surface corroded at $\mathrm{pH} 7.9$ and $p_{\mathrm{H} 2 \mathrm{~S}}=0.83 \mathrm{kPa}$, indicating the specific adsorption of $\mathrm{HS}^{-}(\mathrm{aq})$ or the fast kinetics of mackinawite formation.

\section{Disclaimer}

This report was prepared as an account of work sponsored by an agency of the United States Government. Neither the United States Government nor any agency thereof, nor any of their employees, makes any warranty, express or implied, or assumes any legal liability or responsibility for the accuracy, completeness, or usefulness of any information, apparatus, product, or process disclosed, or represents that its use would not infringe privately owned rights. Reference herein to any specific commercial product, process, or service by trade name, trademark, manufacturer, or otherwise does not necessarily constitute or imply its endorsement, recommendation, or favoring by the United States Government or any agency thereof. The views and opinions of authors expressed herein do not necessarily state or reflect those of the United States Government or any agency thereof.

\section{Acknowledgements}

The authors would like to acknowledge the financial support and collaboration from the U.S. Department of Energy, National Energy Technology Laboratory (DOE-NETL) for this research. We would like to thank OLI systems Inc. for providing access to OLI Analyzer modeling software and, especially, Dr. Andre Anderko for his helpful suggestions on modeling. We would like to thank Mr. Keith Collins from DOE-NETL for his help with microscopic tests. We also want to thank Ian Wolfe and Rosemary Cianni from the Department of Energy and Mineral Engineering, The Pennsylvania State University, for their help with experimental preparation and preliminary data processing. 


\section{References}

[1] M. Ziomek-Moroz, Environmentally Assisted Cracking of Drill Pipes in Deep Drilling Oil and Natural Gas Wells, J. Mater. Eng. Perform. 21 (2011) 1061-1069.

[2] R.A. Carneiro, R.C. Ratnapuli, V. de F.C. Lins, The influence of chemical composition and microstructure of API linepipe steels on hydrogen induced cracking and sulfide stress corrosion cracking, Mater. Sci. Eng. A357 (2003) 104-110.

[3] D.W. Shoesmith, P. Taylor, M.G. Bailey, D.G. Owen, The Formation of Ferrous Monosulfide Polymorphs during the Corrosion of Iron by Aqueous Hydrogen Sulfide at $21^{\circ} \mathrm{C}$, J. Electrochem. Soc. 127 (1980) 1007-1015.

[4] H. Ma, X. Cheng, G. Li, S. Chen, Z. Quan, S. Zhao, L. Niu, The influence of hydrogen sulfide on corrosion of iron under different conditions, Corros. Sci. 42 (2000) 1669-1683.

[5] J.O. Bockris, D. Drazic, A.R. Despic, The Electrode Kinetics of the Deposition and Dissolution of Iron, Electrochim. Acta. 4 (1961) 325-361.

[6] E. Abelev, T.A. Ramanarayanan, S.L. Bernasek, Iron Corrosion in $\mathrm{CO}_{2} /$ Brine at Low $\mathrm{H}_{2} \mathrm{~S}$ Concentrations: An Electrochemical and Surface Science Study, J. Electrochem. Soc. 156 (2009) C331-C339.

[7] J. Banaś, U. Lelek-Borkowska, B. Mazurkiewicz, W. Solarski, Effect of $\mathrm{CO}_{2}$ and $\mathrm{H}_{2} \mathrm{~S}$ on the composition and stability of passive film on iron alloys in geothermal water, Electrochim. Acta. 52 (2007) 5704-5714.

[8] J.L. Crolet, N. Thevenot, S. Nesic, Role of Conductive Corrosion Products in the Protectiveness of Corrosion Layers, Corrosion. 54 (1998) 194-203.

[9] J.B. Sardisco, R.E. Pitts, Corrosion of Iron in an $\mathrm{H}_{2} \mathrm{~S}-\mathrm{CO}_{2}-\mathrm{H}_{2} \mathrm{O}$ System Composition and 
Protectiveness of the Sulfide Film as a Function of pH, Corrosion. 21 (1965) 350-354.

[10] W. Sun, S. Nešić, S. Papavinasam, Kinetics of Iron Sulfide and Mixed Iron Sulfide/Carbonate Scale Precipitation in $\mathrm{CO}_{2} / \mathrm{H}_{2} \mathrm{~S}$ Corrosion, NACE Corros. (2006) No. 06644.

[11] S.N. Smith, Current Understanding of Corrosion Mechanisms Due to $\mathrm{H}_{2} \mathrm{~S}$ in Oil and Gas Production Environments, NACE Corros. (2015) No. 5485.

[12] J. Kittel, F. Ropital, F. Grosjean, E.M.M. Sutter, B. Tribollet, Corrosion mechanisms in aqueous solutions containing dissolved $\mathrm{H}_{2} \mathrm{~S}$. Part 1: Characterisation of $\mathrm{H}_{2} \mathrm{~S}$ reduction on a 316L rotating disc electrode, Corros. Sci. 66 (2013) 324-329.

[13] B.J. Berkowitz, H.H. Horowitz, The Role of $\mathrm{H}_{2} \mathrm{~S}$ in the Corrosion and Hydrogen Embrittlement of Steel, J. Electrochem. Soc. 129 (1982) 468-474.

[14] F. Pessu, R. Barker, A. Neville, Early stages of pitting corrosion of UNS K03014 carbon steel in sour corrosin environments: The influence of $\mathrm{CO}_{2}, \mathrm{H}_{2} \mathrm{~S}$ and temperature, NACE Corros. (2015) No. 5583.

[15] W. Sun, S. Nešić, A Mechanistic Model of $\mathrm{H}_{2}$ S Corrosion of Mild Steel, NACE Corros. (2007) No. 07655 .

[16] J. Tang, Y. Shao, J. Guo, T. Zhang, G. Meng, F. Wang, The effect of $\mathrm{H}_{2} \mathrm{~S}$ concentration on the corrosion behavior of carbon steel at $90{ }^{\circ} \mathrm{C}$, Corros. Sci. 52 (2010) 2050-2058.

[17] H. Vedage, T.A. Ramanarayanan, J.D. Mumford, S.N. Smith, Electrochemical Growth of Iron Sulfide Films in $\mathrm{H}_{2} \mathrm{~S}$-Saturated Chloride Media, Corrosion. 49 (1993) 114-121.

[18] L. Zhang, W. Zhong, J. Yang, T. Gu, X. Xiao, M. Lu, Effects of Temperature and Partial Pressure on $\mathrm{H}_{2} \mathrm{~S} / \mathrm{CO}_{2}$ Corrosion of Pipeline Steel in Sour Conditions, NACE Corros. (2011) No. 11079.

[19] Y. Zheng, J. Ning, B. Brown, S. Nesic, Electrochemical Model of Mild Steel Corrosion in a 
Mixed $\mathrm{H}_{2} \mathrm{~S} / \mathrm{CO}_{2}$ Aqueous Environment in the Absence of Protective Corrosion Product Layers, Corrosion. 71 (2015) 316-325.

[20] R. Cabrera-Sierra, I. García, E. Sosa, T. Oropeza, I. González, Electrochemical behavior of carbon steel in alkaline sour environments measured by electrochemical impedance spectroscopy, Electrochim. Acta. 46 (2000) 487-497.

[21] M. Ziomek-Moroz, J.A. Hawk, T. Ramgopal, F. Gui, Surface Studies of Ultra-high Strength Drilling Steel after Corrosion Fatigue in Simulated Sour Environment, ECS Trans. 45 (2013) 5162.

[22] M. Ziomek-Moroz, J.A. Hawk, R. Thodla, F. Gui, Effect of Sour Environment pH on Crack Morphology in Ultra-High Strength Drilling Steel Under Cyclic Stress, ECS Trans. 50 (2013) 7990.

[23] T. Ramgopal, F. Gui, J. Hawk, M. Ziomek-Moroz, Corrosion Fatigue Performance of High Strength Drill Pipe in Sour Environments, NACE Corros. (2011) No. 11108.

[24] R.F. Schaller, J.R. Scully, Spatial determination of diffusible hydrogen concentrations proximate to pits in a Fe-Cr-Ni-Mo steel using the Scanning Kelvin Probe, Electrochem. Commun. 63 (2016) 5-9.

[25] R. Feng, J.R. Beck, S.N. Lvov, M. Ziomek-Moroz, Effects of Hydrogen Sulfide on the Corrosion Behavior of High Strength Steel in Alkaline Solutions, ECS Trans. 61 (2014) 97-114.

[26] R. Feng, J.R. Beck, R. Cianni, S.N. Lvov, M. Ziomek-Moroz, Corrosion of Carbon Steels in $\mathrm{H}_{2} \mathrm{~S}-$ Containing Alkaline Brines, NACE Corros. (2015) No. 6119.

[27] K. Videm, A.M. Koren, Corrosion, Passivity, and Pitting of Carbon Steel in Aqueous Solutions of $\mathrm{HCO}_{3}{ }^{-}, \mathrm{CO}_{2}$, and $\mathrm{Cl}^{-}$, Corrosion. 49 (1993) 746-754.

[28] J. Han, J. Zhang, J.W. Carey, Effect of bicarbonate on corrosion of carbon steel in $\mathrm{CO}_{2}$ saturated 
brines, Int. J. Greenh. Gas Control. 5 (2011) 1680-1683.

[29] K.A. Rozman, Corrosion and Fatigue of Oil Well Drilling Steels, Oregon State University, 2011.

[30] S.N. Lvov, Introduction to Electrochemical Science and Engineering, CRC Press, 2015.

[31] P. Wang, A. Anderko, R.D. Young, A speciation-based model for mixed-solvent electrolyte systems, Fluid Phase Equilib. 203 (2002) 141-176.

[32] M. Stern, A.L. Geary, Electrochemical Polarization: I. A Theoretical Analysis of the Shape of Polarization Curves, J. Electrochem. Soc. 104 (1957) 56-63.

[33] M. Stern, A method for determining corrosion rates from linear polarization data, Corrosion. 14 (1958) 60-64.

[34] Y. V. Shvarov, Algorithmization of the Numeric Equilibrium Modeling of Dynamic Geochemical Processes, Geochemistry Int. 37 (1999) 571-576.

[35] K. Videm, J. Kvarekvål, Corrosion of Carbon Steel in Carbon Dioxide-Saturated Solutions Containing Small Amounts of Hydrogen Sulfide, Corrosion. 51 (1995) 260-269.

[36] Z.A. Iofa, V.V. Batrakov, Influence of anion adsorption on the action of inhibitors on the acid corrosion of iron and cobalt, Electrochim. Acta. 9 (1964) 1645-1653.

[37] D. Landolt, Corrosion and Surface Chemistry of Metals, EPFL Press, 2007.

[38] M. Stern, The Electrochemical Behavior, Including Hydrogen Over-voltage, of Iron in Acid Environments, J. Electrochem. Soc. 102 (1955) 609-612.

[39] E. Barsoukov, J.R. Macdonald, Impedance Spectroscopy: Theory, Experiment, and Applications, John Wiley \& Sons, Inc., 2005.

[40] J.R. Park, D.D. Macdonald, Impedance studies of the growth of porous magnetite films on carbon steel in high temperature aqueous systems, Corros. Sci. 23 (1983) 295-315. 
[41] F.E. Heakal, K.A. Awad, Electrochemical corrosion and passivation behavior of titanium and its Ti-6Al-4V alloy in low and highly concentrated HBr solutions, Int. J. Electrochem. Sci. 6 (2011) 6483-6502.

[42] A. Anderko, S.J. Sanders, R.D. Young, Real-Solution Stability Diagrams: A Thermodynamic Tool for Modeling Corrosion in Wide Temperature and Concentration Ranges, Corrosion. 53 (1997) 43-53.

[43] F. Shi, L. Zhang, J. Yang, M. Lu, J. Ding, H. Li, Polymorphous FeS corrosion products of pipeline steel under highly sour conditions, Corros. Sci. 102 (2016) 103-113. 


\section{Appendix}

Volmer-Heyrovsky mechanism[37]

$$
\begin{array}{ll}
\text { Step I (RDS): } & \mathrm{H}^{+}(\mathrm{aq})+\mathrm{e}^{-} \rightarrow \mathrm{H}(\mathrm{ad}) \\
\text { Step II: } & \mathrm{H}^{+}(\mathrm{aq})+\mathrm{H}(\mathrm{ad})+\mathrm{e}^{-} \leftrightarrow \mathrm{H}_{2}(\mathrm{~g}) \\
& b_{c}=-\frac{2.303 R T}{\beta F}
\end{array}
$$

Volmer-Tafel mechanism[37]

$$
\begin{array}{ll}
\text { Step I: } & \mathrm{H}^{+}(\mathrm{aq})+\mathrm{e}^{-} \leftrightarrow \mathrm{H}(\mathrm{ad}) \quad \mid 2 \mathrm{x} \\
\text { Step II (RDS): } & 2 \mathrm{H}(\mathrm{ad}) \rightarrow \mathrm{H}_{2}(\mathrm{~g}) \\
& b_{c}=-\frac{2.303 R T}{2 F}
\end{array}
$$




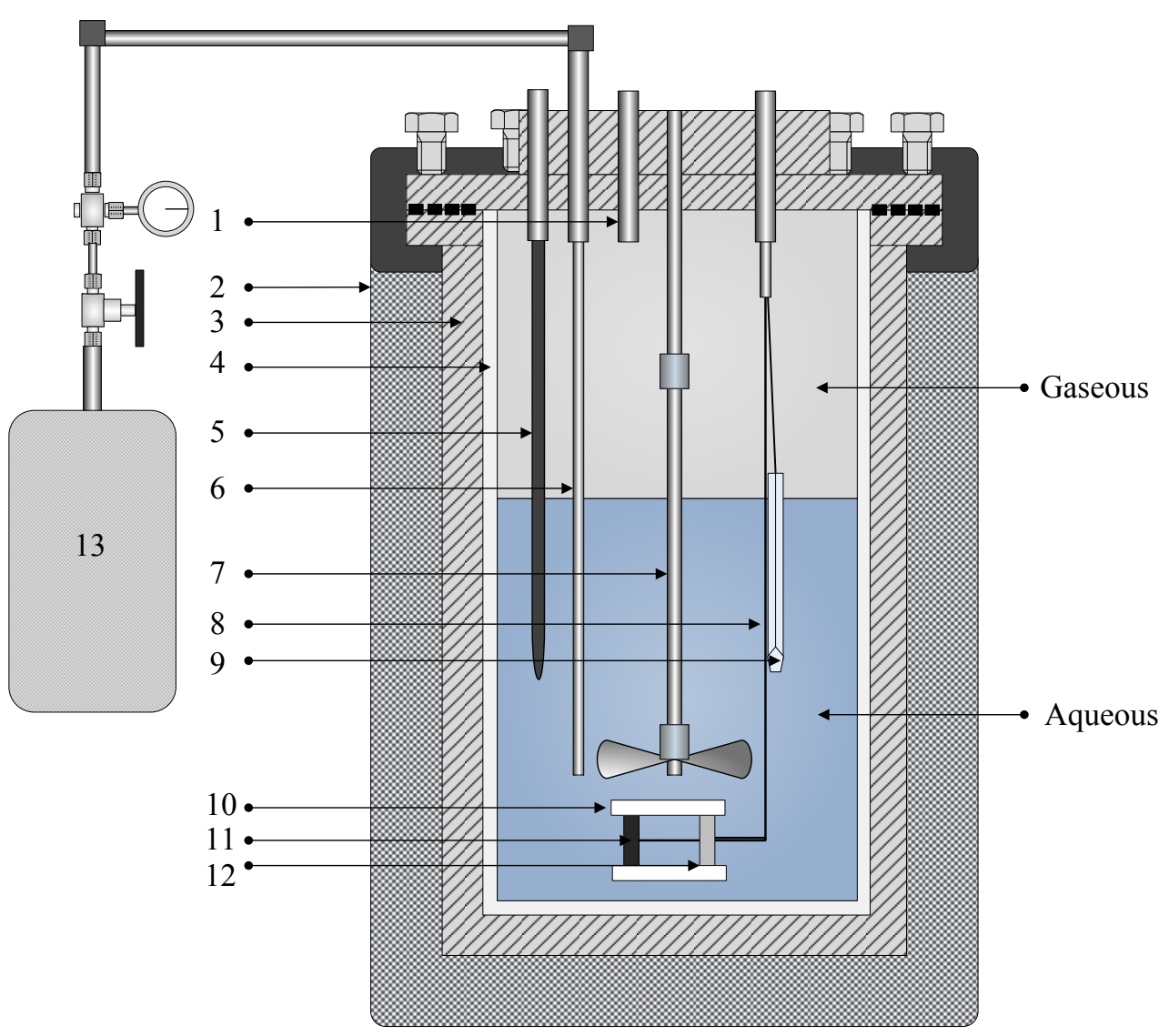

Fig. 1. Schematic diagram of the autoclave system.

1- Connection to pressure transducer; 2- Heating mantle; 3- Autoclave stainless steel vessel; 4- PTFE liner; 5- Polymer-coated thermocouple; 6- PEEK tubing; 7- Epoxy-coated stirrer; 8- PTFE-coated electrode lead; 9- $\mathrm{Ag} / \mathrm{AgCl}$ reference electrode; 10- PTFE assembly; 11- Steel working electrode; 12- Pt counter electrode; $13-\mathrm{H}_{2} \mathrm{~S} / \mathrm{N}_{2}$ cylinder. 


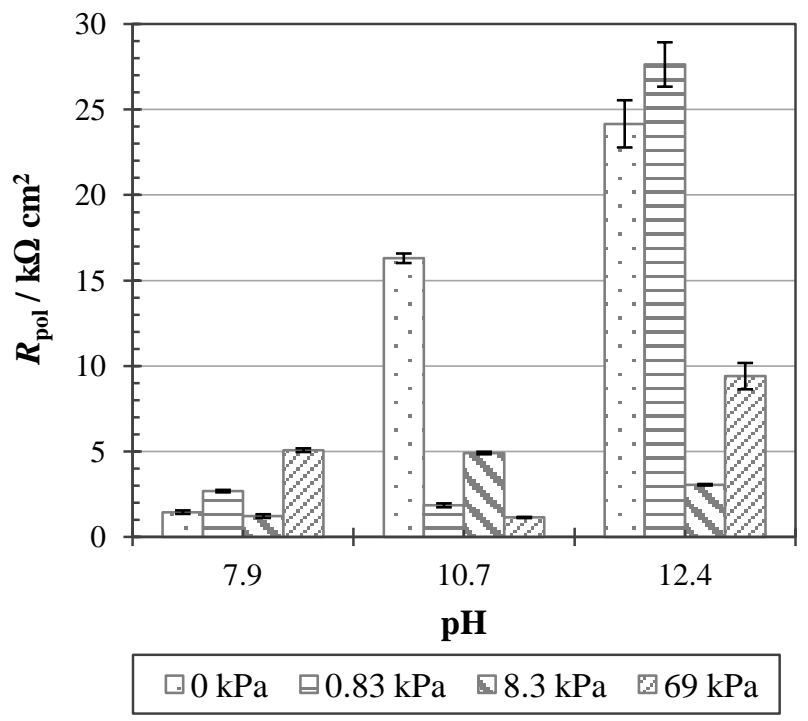

Fig. 2. Experimental $R_{\text {pol }}$ after 60 hours in the three solutions at $p_{\mathrm{H} 2 \mathrm{~S}}=0 \mathrm{kPa}, 0.83 \mathrm{kPa}\left(2.63 \times 10^{-}\right.$ $\left.{ }^{4} \mathrm{~mol} \mathrm{~kg}^{-1} \mathrm{H}_{2} \mathrm{~S}\right), 8.3 \mathrm{kPa}\left(2.63 \times 10^{-3} \mathrm{~mol} \mathrm{~kg}^{-1} \mathrm{H}_{2} \mathrm{~S}\right)$, and $69 \mathrm{kPa}\left(2.19 \times 10^{-2} \mathrm{~mol} \mathrm{~kg}^{-1} \mathrm{H}_{2} \mathrm{~S}\right)$ at $85{ }^{\circ} \mathrm{C}$. Conditions: Solution \#1: $0.9 \mathrm{~mol} \mathrm{~kg}{ }^{-1} \mathrm{NaCl}, 0.5 \mathrm{~mol} \mathrm{~kg}^{-1} \mathrm{NaHCO}_{3}, \mathrm{pH}=7.9$; Solution \#2: 0.9 mol kg ${ }^{-1} \mathrm{NaCl}, 1 \mathrm{~mol} \mathrm{~kg}{ }^{-1} \mathrm{Na}_{2} \mathrm{CO}_{3}, \mathrm{pH}=10.7$; Solution \#3: $0.9 \mathrm{~mol} \mathrm{~kg}{ }^{-1} \mathrm{NaCl}, 1 \mathrm{~mol} \mathrm{~kg}^{-1}$ $\mathrm{Na}_{2} \mathrm{CO}_{3}, 1 \mathrm{~mol} \mathrm{~kg}{ }^{-1} \mathrm{NaOH}, \mathrm{pH}=12.4$. 


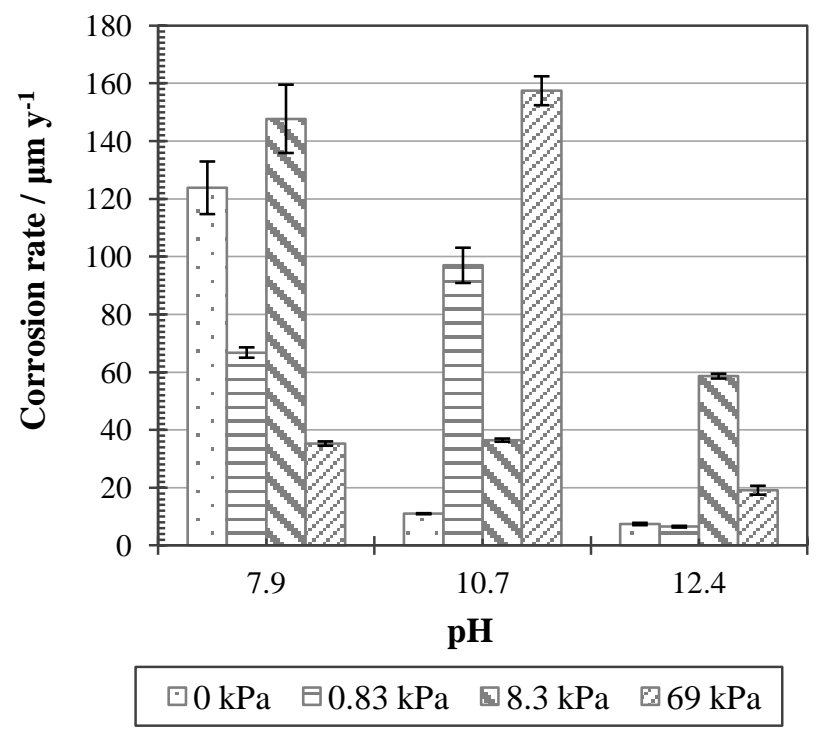

Fig. 3. Experimental corrosion rates after 60 hours in the three solutions at $p_{\mathrm{H} 2 \mathrm{~S}}=0 \mathrm{kPa}, 0.83$ $\mathrm{kPa}\left(2.63 \times 10^{-4} \mathrm{~mol} \mathrm{~kg}^{-1} \mathrm{H}_{2} \mathrm{~S}\right), 8.3 \mathrm{kPa}\left(2.63 \times 10^{-3} \mathrm{~mol} \mathrm{~kg}^{-1} \mathrm{H}_{2} \mathrm{~S}\right)$, and $69 \mathrm{kPa}\left(2.19 \times 10^{-2} \mathrm{~mol} \mathrm{~kg}^{-1}\right.$ $\mathrm{H}_{2} \mathrm{~S}$ ) at $85^{\circ} \mathrm{C}$. Conditions: Solution \#1: $0.9 \mathrm{~mol} \mathrm{~kg}^{-1} \mathrm{NaCl}, 0.5 \mathrm{~mol} \mathrm{~kg}^{-1} \mathrm{NaHCO}_{3}, \mathrm{pH}=7.9$;

Solution \#2: $0.9 \mathrm{~mol} \mathrm{~kg}^{-1} \mathrm{NaCl}, 1 \mathrm{~mol} \mathrm{~kg}^{-1} \mathrm{Na}_{2} \mathrm{CO}_{3}, \mathrm{pH}=10.7$; Solution \#3: $0.9 \mathrm{~mol} \mathrm{~kg}^{-1} \mathrm{NaCl}, 1$ mol kg-1 $\mathrm{Na}_{2} \mathrm{CO}_{3}, 1 \mathrm{~mol} \mathrm{~kg}^{-1} \mathrm{NaOH}, \mathrm{pH}=12.4$. 


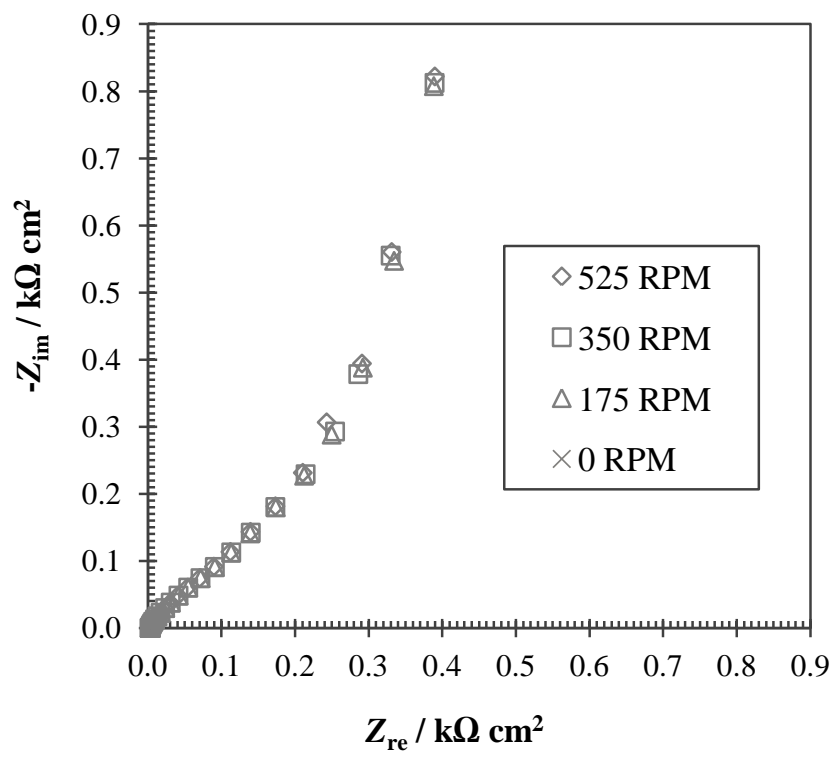

Fig. 4. The Nyquist plots for UD-165 at different stir rates after being corroded for 60 hours in Solution \#2 at $p_{\mathrm{H} 2 \mathrm{~S}}=69 \mathrm{kPa}\left(2.19 \times 10^{-2} \mathrm{~mol} \mathrm{~kg}^{-1} \mathrm{H}_{2} \mathrm{~S}\right)$ at $85^{\circ} \mathrm{C}$. Conditions: Solution \#2: 0.9 mol $\mathrm{kg}^{-1} \mathrm{NaCl}, 1 \mathrm{~mol} \mathrm{~kg}^{-1} \mathrm{Na}_{2} \mathrm{CO}_{3}, \mathrm{pH}=10.5$. 


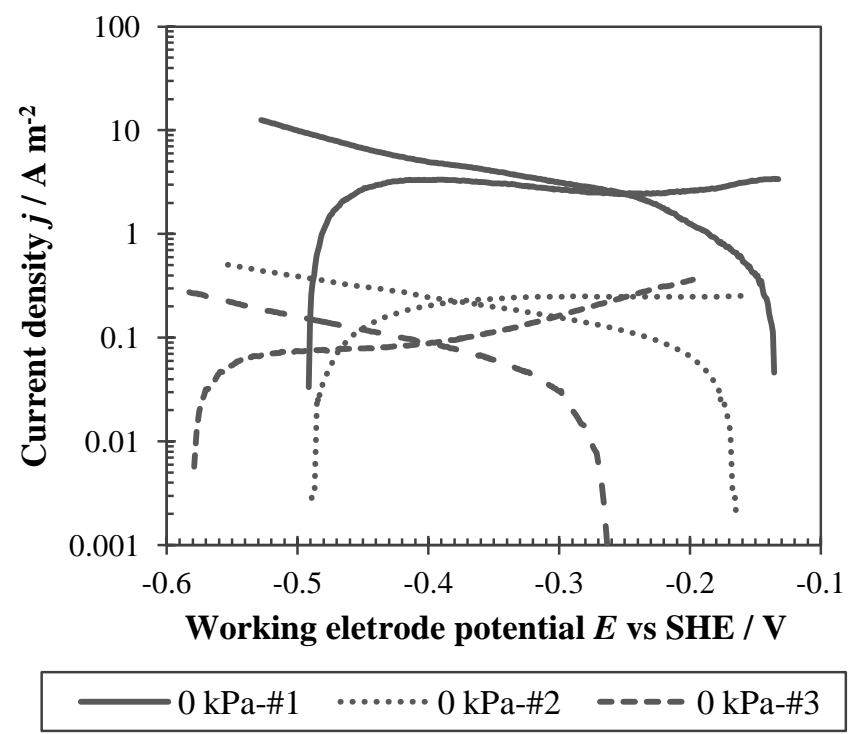

Fig. 5. The LSV plots of UD- 165 at $p_{\mathrm{H} 2 \mathrm{~S}}=0 \mathrm{kPa}$ in the three solutions at $85^{\circ} \mathrm{C}$ with a sweep rate of $5 \mathrm{mV} \mathrm{s}^{-1}$. Conditions: Solution \#1: $0.9 \mathrm{~mol} \mathrm{~kg}^{-1} \mathrm{NaCl}, 0.5 \mathrm{~mol} \mathrm{~kg}^{-1} \mathrm{NaHCO}_{3}, \mathrm{pH}=7.9$; Solution \#2: $0.9 \mathrm{~mol} \mathrm{~kg}{ }^{-1} \mathrm{NaCl}, 1 \mathrm{~mol} \mathrm{~kg}^{-1} \mathrm{Na}_{2} \mathrm{CO}_{3}, \mathrm{pH}=10.7$; Solution \#3: $0.9 \mathrm{~mol} \mathrm{~kg}^{-1} \mathrm{NaCl}, 1$ mol kg ${ }^{-1} \mathrm{Na}_{2} \mathrm{CO}_{3}, 1 \mathrm{~mol} \mathrm{~kg}^{-1} \mathrm{NaOH}, \mathrm{pH}=12.4$. 


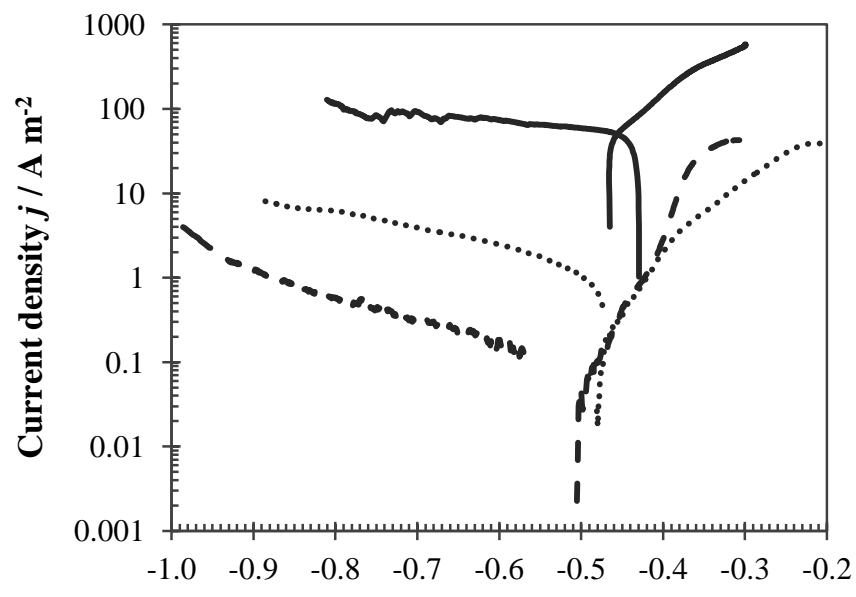

Working electrode potential $E$ vs SHE / V

69kPa-\#1 $\cdots \cdots \cdots \cdot 69 \mathrm{kPa}-\# 2 \quad--\cdot 69 \mathrm{kPa}-\# 3$

Fig. 6. The LSV plots of UD-165 at $p_{\mathrm{H} 2 \mathrm{~S}}=69 \mathrm{kPa}\left(2.19 \times 10^{-2} \mathrm{~mol} \mathrm{~kg}^{-1} \mathrm{H}_{2} \mathrm{~S}\right)$ in the three solutions at $85{ }^{\circ} \mathrm{C}$ with a sweep rate of $2 \mathrm{mV} \mathrm{s}^{-1}$. Conditions: Solution \#1: $0.9 \mathrm{~mol} \mathrm{~kg} \mathrm{NaCl}^{-1} 0.5$ mol kg ${ }^{-1} \mathrm{NaHCO}_{3}, \mathrm{pH}=7.7$; Solution \#2: $0.9 \mathrm{~mol} \mathrm{~kg}^{-1} \mathrm{NaCl}, 1 \mathrm{~mol} \mathrm{~kg}^{-1} \mathrm{Na}_{2} \mathrm{CO}_{3}, \mathrm{pH}=10.5$; Solution \#3: $0.9 \mathrm{~mol} \mathrm{~kg}^{-1} \mathrm{NaCl}, 1 \mathrm{~mol} \mathrm{~kg}^{-1} \mathrm{Na}_{2} \mathrm{CO}_{3}, 1 \mathrm{~mol} \mathrm{~kg}^{-1} \mathrm{NaOH}, \mathrm{pH}=12.4$. 

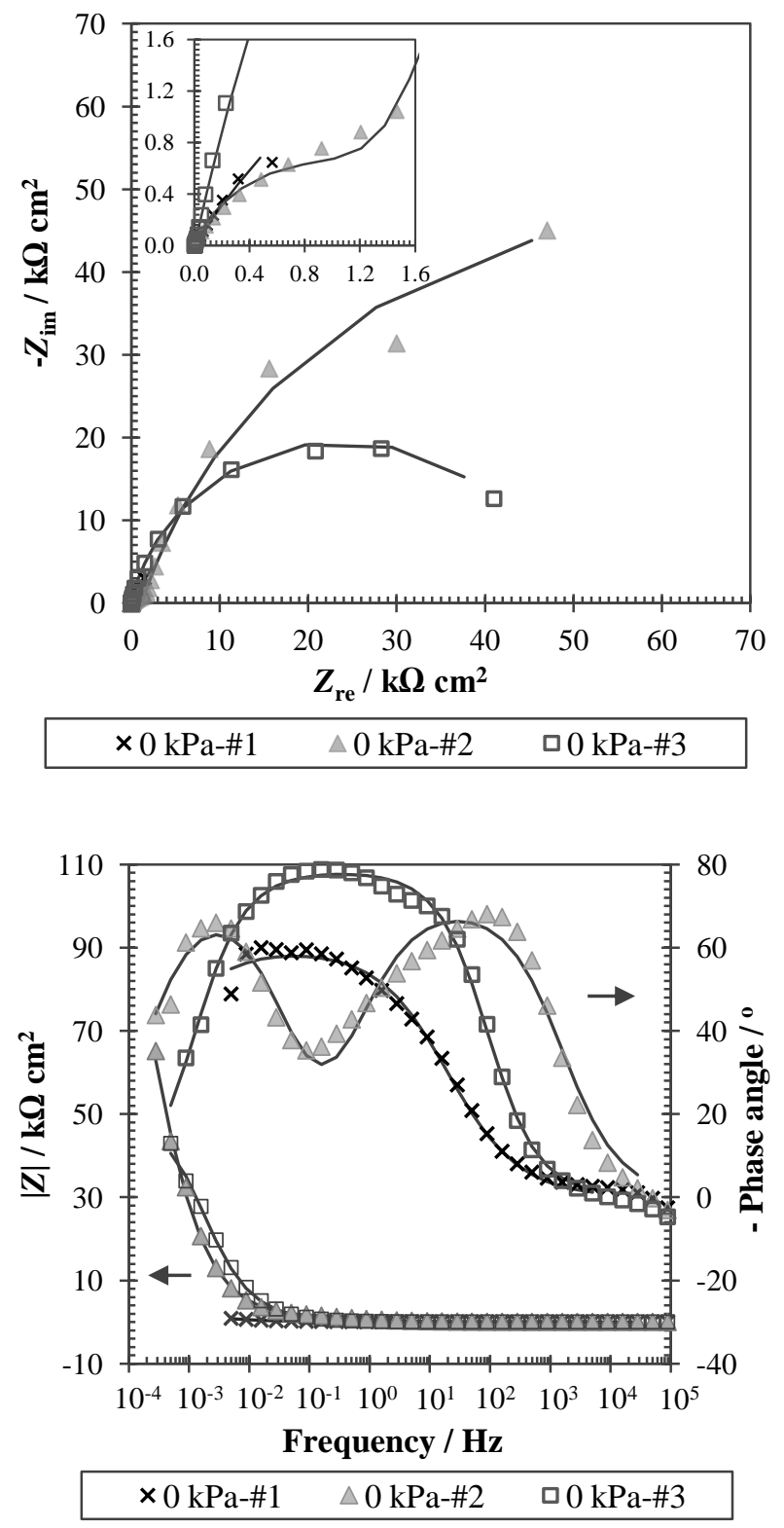
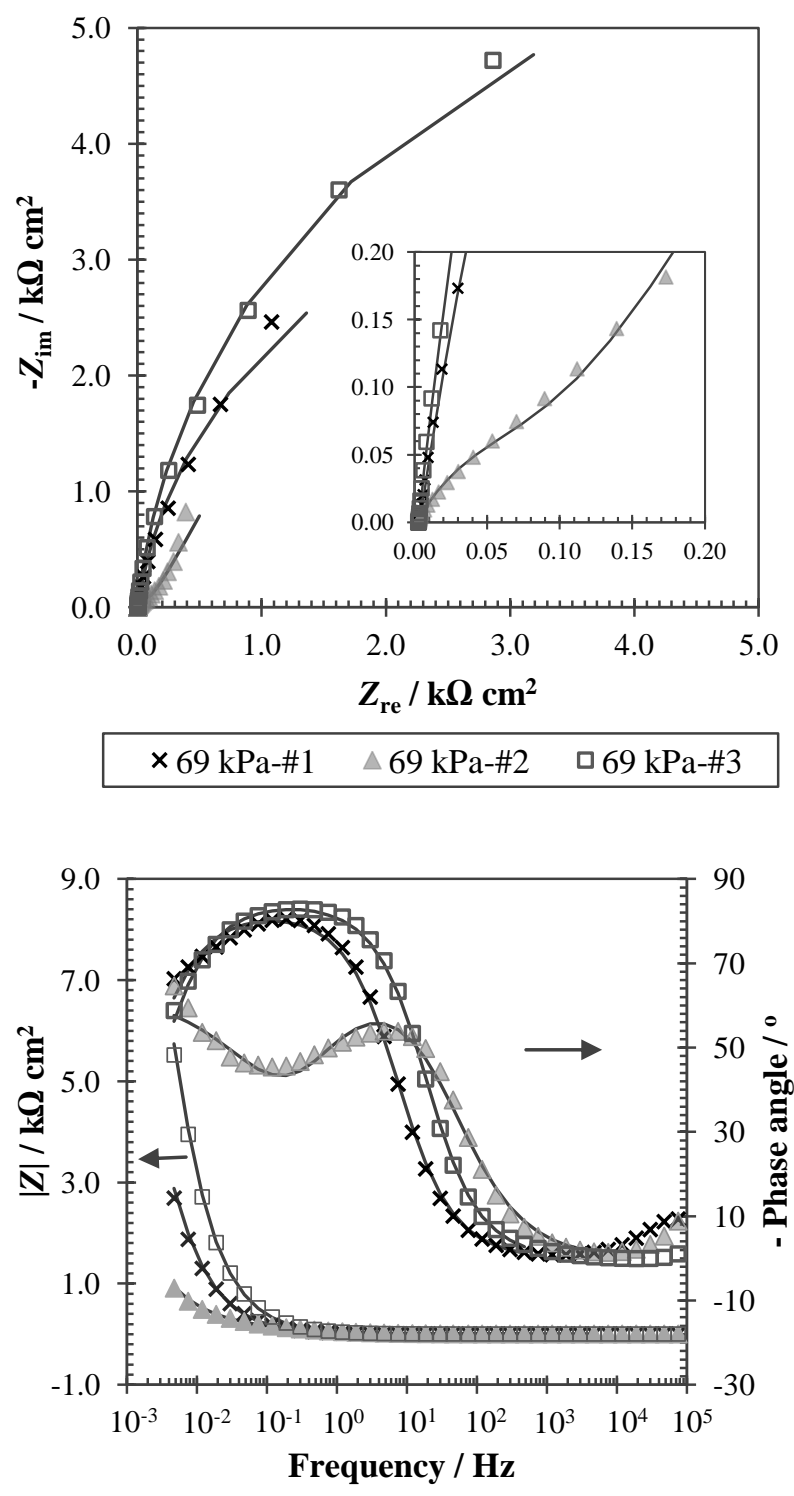

$\times 69 \mathrm{kPa}-\# 1 \quad \triangle 69 \mathrm{kPa}-\# 2 \quad \square 69 \mathrm{kPa}-\# 3$

Fig. 7. Nyquist (top) and Bode (bottom) plots of UD-165 samples after 60 hours in the three solutions at $p_{\mathrm{H} 2 \mathrm{~S}}=0 \mathrm{kPa}$ and $69 \mathrm{kPa}\left(2.19 \times 10^{-2} \mathrm{~kg} \mathrm{~mol}^{-1} \mathrm{H}_{2} \mathrm{~S}\right)$ at $85^{\circ} \mathrm{C}$. Conditions: Solution \#1: $0.9 \mathrm{~mol} \mathrm{~kg}{ }^{-1} \mathrm{NaCl}, 0.5 \mathrm{~mol} \mathrm{~kg}^{-1} \mathrm{NaHCO}_{3}, \mathrm{pH}=7.9$; Solution \#2: $0.9 \mathrm{~mol} \mathrm{~kg}{ }^{-1} \mathrm{NaCl}, 1 \mathrm{~mol} \mathrm{~kg}^{-1}$ $\mathrm{Na}_{2} \mathrm{CO}_{3}, \mathrm{pH}=10.7$; Solution \#3: $0.9 \mathrm{~mol} \mathrm{~kg}{ }^{-1} \mathrm{NaCl}, 1 \mathrm{~mol} \mathrm{~kg}^{-1} \mathrm{Na}_{2} \mathrm{CO}_{3}, 1 \mathrm{~mol} \mathrm{~kg}^{-1} \mathrm{NaOH}, \mathrm{pH}=$ 12.4. The symbols represent the experimental EIS results and the lines represent the fitting results based on the equivalent circuits in Fig. 8. 
(a)

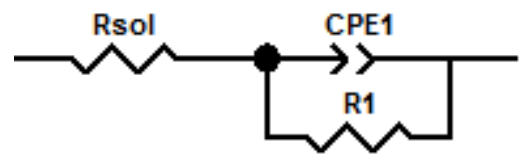

(b)

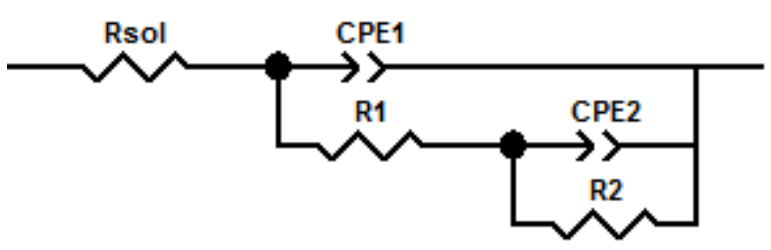

Fig. 8. The equivalent electrical circuits to fit the EIS data at $p_{\mathrm{H} 2 \mathrm{~S}}=0 \mathrm{kPa}$ and $69 \mathrm{kPa}\left(2.19 \times 10^{-2}\right.$ mol $\mathrm{kg}^{-1} \mathrm{H}_{2} \mathrm{~S}$ ) at $85{ }^{\circ} \mathrm{C}$. Circuit (a) for Solutions \#1 and \#3 and (b) for Solution \#2 in Fig. 7. Conditions: Solution \#1: $0.9 \mathrm{~mol} \mathrm{~kg}^{-1} \mathrm{NaCl}, 0.5 \mathrm{~mol} \mathrm{~kg}^{-1} \mathrm{NaHCO}_{3}, \mathrm{pH}=7.9$; Solution \#2: 0.9 mol kg ${ }^{-1} \mathrm{NaCl}, 1 \mathrm{~mol} \mathrm{~kg}^{-1} \mathrm{Na}_{2} \mathrm{CO}_{3}, \mathrm{pH}=10.7$; Solution \#3: $0.9 \mathrm{~mol} \mathrm{~kg}^{-1} \mathrm{NaCl}, 1 \mathrm{~mol} \mathrm{~kg}{ }^{-1}$ $\mathrm{Na}_{2} \mathrm{CO}_{3}, 1 \mathrm{~mol} \mathrm{~kg}^{-1} \mathrm{NaOH}, \mathrm{pH}=12.4$. 


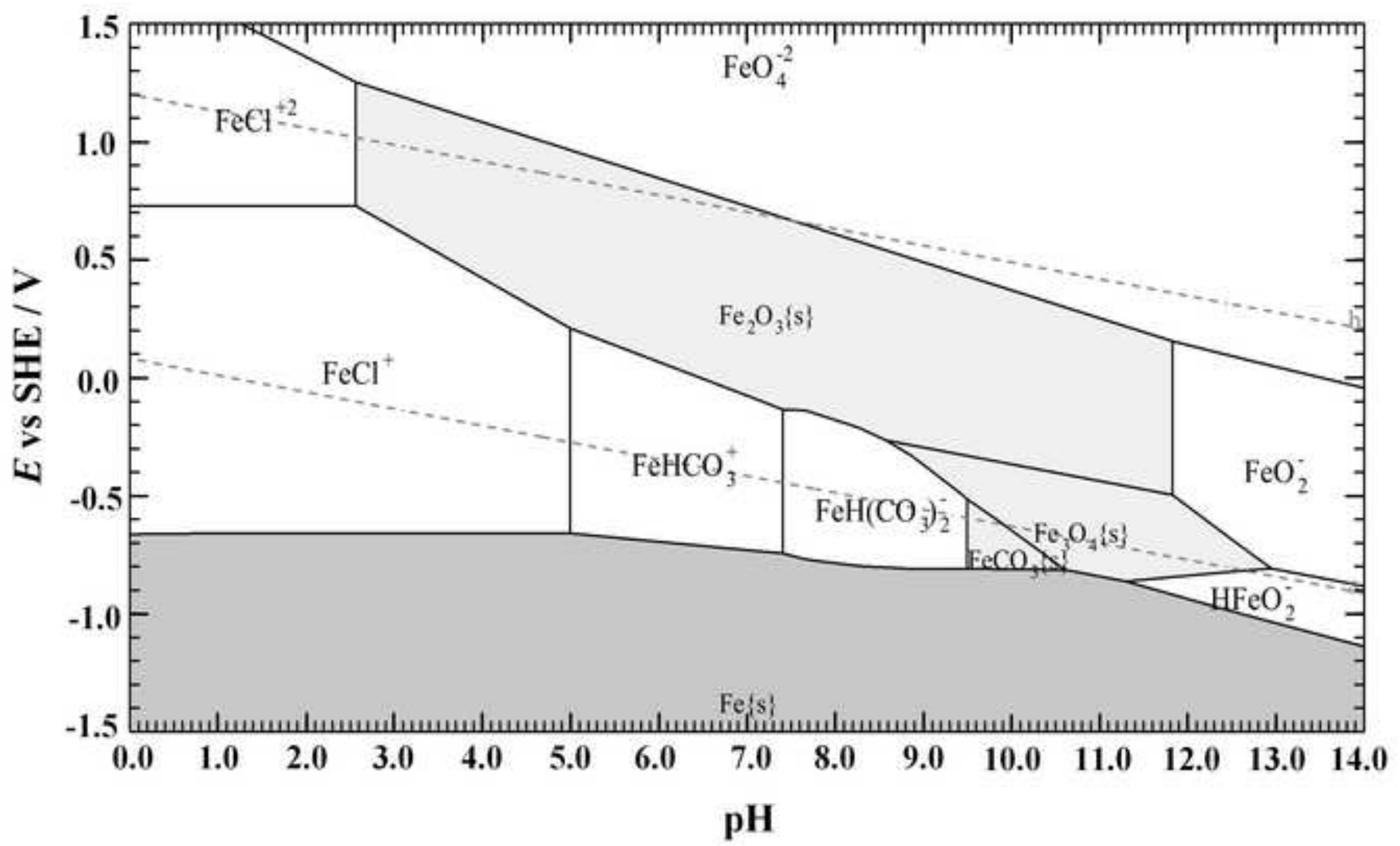




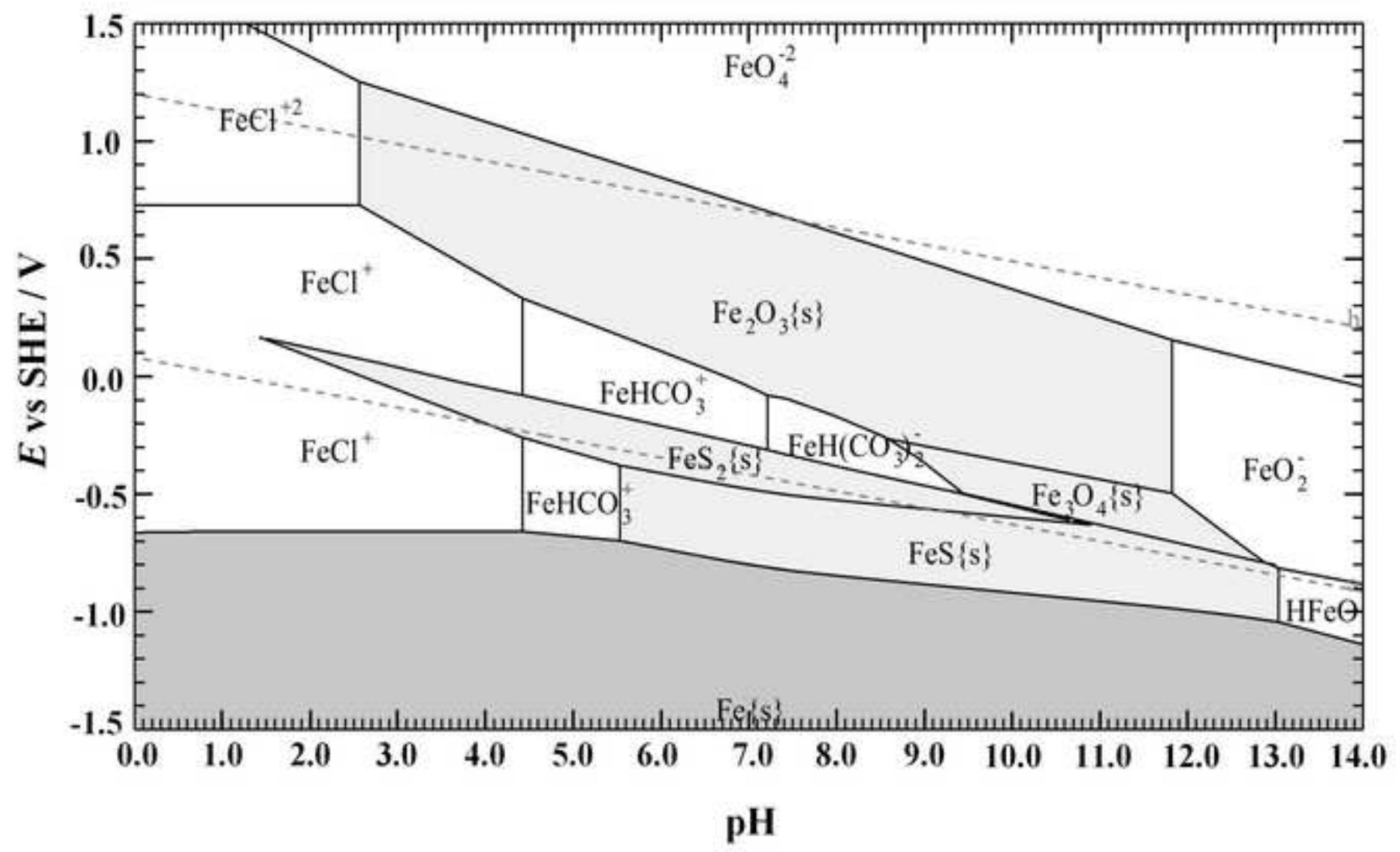




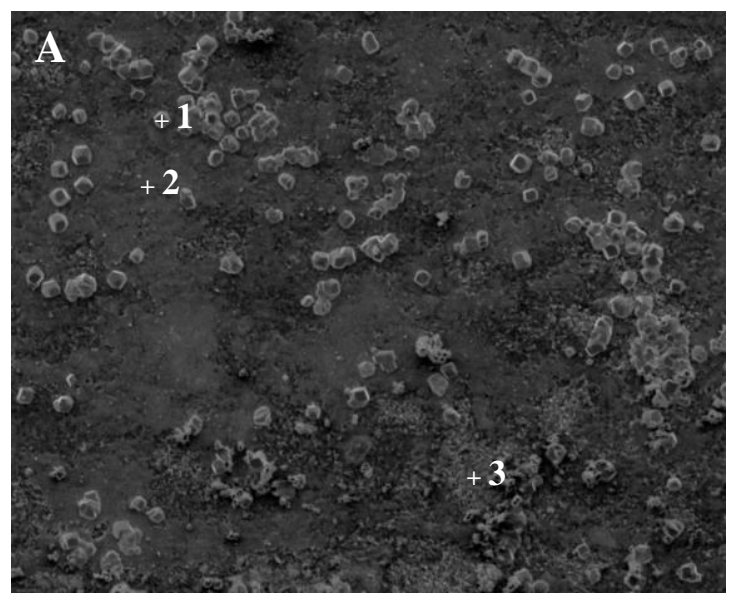

$100 \mu \mathrm{m}$

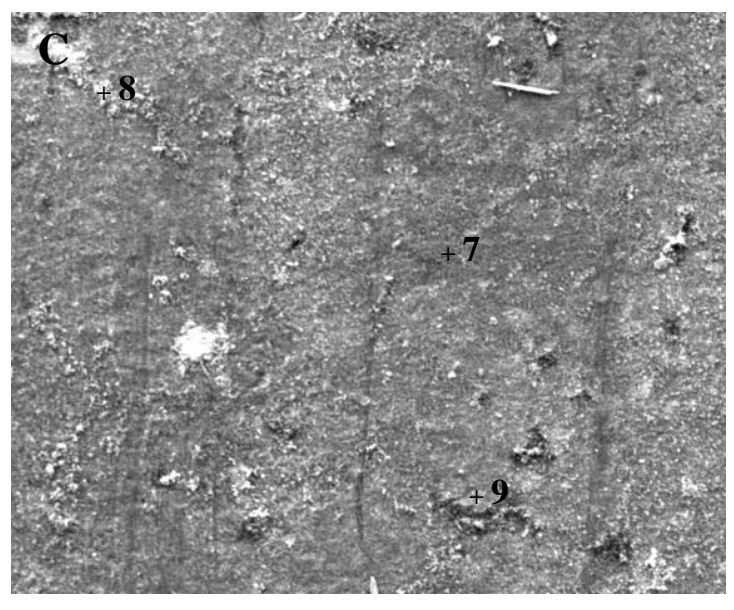

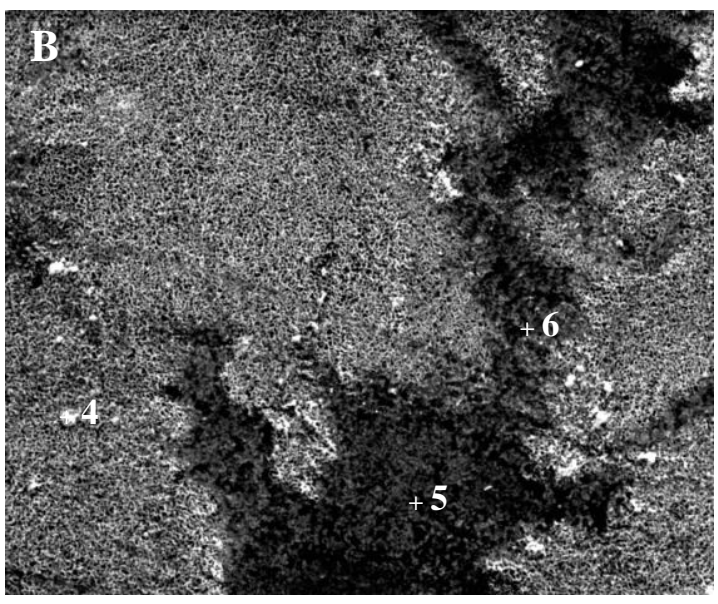

$100 \mu \mathrm{m}$

$100 \mu \mathrm{m}$

Fig. 11. SEM images of UD-165 steel surfaces after the corrosion tests $(\sim 84$ hours $)$ at $p_{\mathrm{H} 2 \mathrm{~S}}=0$

$\mathrm{kPa}$ and $85^{\circ} \mathrm{C}$. A - Solution \#1: $0.9 \mathrm{~mol} \mathrm{~kg}^{-1} \mathrm{NaCl}, 0.5 \mathrm{~mol} \mathrm{~kg}{ }^{-1} \mathrm{NaHCO}_{3}, \mathrm{pH}=7.9$; $\mathrm{B}$ - Solution \#2: $0.9 \mathrm{~mol} \mathrm{~kg}^{-1} \mathrm{NaCl}, 1 \mathrm{~mol} \mathrm{~kg}{ }^{-1} \mathrm{Na}_{2} \mathrm{CO}_{3}, \mathrm{pH}=10.7$; $\mathrm{C}$ - Solution \#3: 0.9 mol kg${ }^{-1} \mathrm{NaCl}, 1 \mathrm{~mol}$ $\mathrm{kg}^{-1} \mathrm{Na}_{2} \mathrm{CO}_{3}, 1 \mathrm{~mol} \mathrm{~kg}{ }^{-1} \mathrm{NaOH}, \mathrm{pH}=12.4$. 


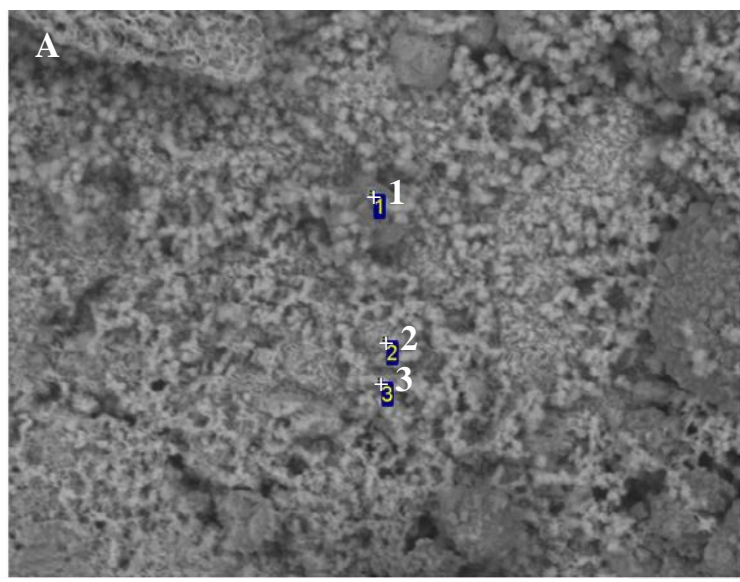

$10 \mu \mathrm{m}$

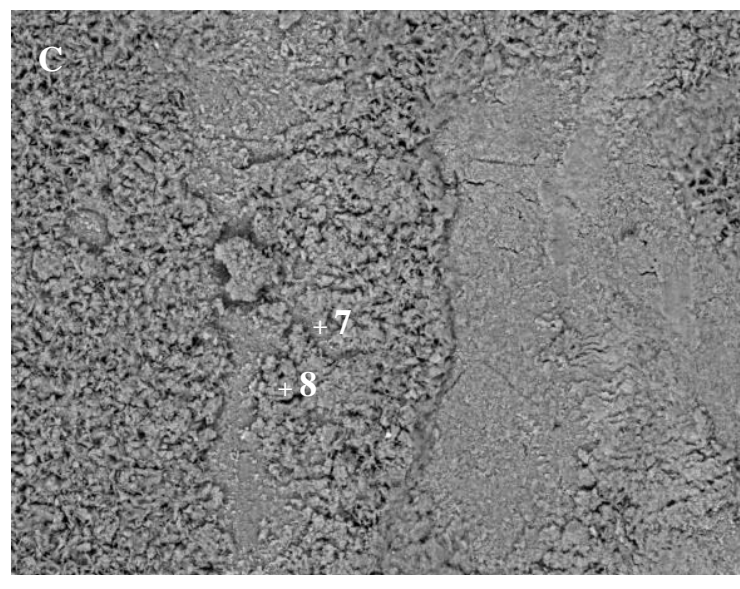

$10 \mu \mathrm{m}$

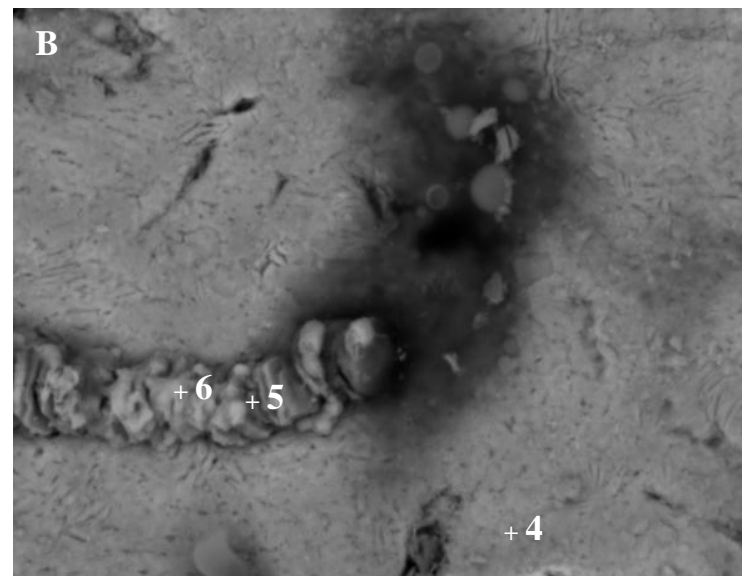

$6 \mu \mathrm{m}$

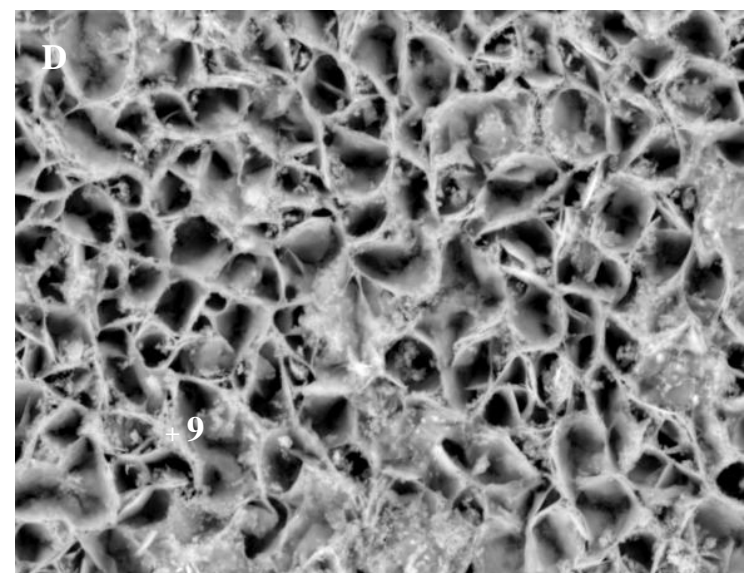

$6 \mu \mathrm{m}$

Fig. 12. SEM images of UD-165 steel surfaces after the corrosion tests $(\sim 84$ hours $)$ at $p_{\mathrm{H} 2 \mathrm{~S}}=69$

$\mathrm{kPa}\left(2.19 \times 10^{-2} \mathrm{~mol} \mathrm{~kg}^{-1} \mathrm{H}_{2} \mathrm{~S}\right)$ and $85^{\circ} \mathrm{C}$. A - Solution \#1: $0.9 \mathrm{~mol} \mathrm{~kg}^{-1} \mathrm{NaCl}, 0.5 \mathrm{~mol} \mathrm{~kg}^{-1}$

$\mathrm{NaHCO}_{3}, \mathrm{pH}=7.7$; $\mathrm{B}$ - Solution \#2: $0.9 \mathrm{~mol} \mathrm{~kg}^{-1} \mathrm{NaCl}, 1 \mathrm{~mol} \mathrm{~kg}^{-1} \mathrm{Na}_{2} \mathrm{CO}_{3}, \mathrm{pH}=10.5$; C and D -

Solution \#3: $0.9 \mathrm{~mol} \mathrm{~kg}^{-1} \mathrm{NaCl}, 1 \mathrm{~mol} \mathrm{~kg}^{-1} \mathrm{Na}_{2} \mathrm{CO}_{3}, 1 \mathrm{~mol} \mathrm{~kg}^{-1} \mathrm{NaOH}, \mathrm{pH}=12.4$. 


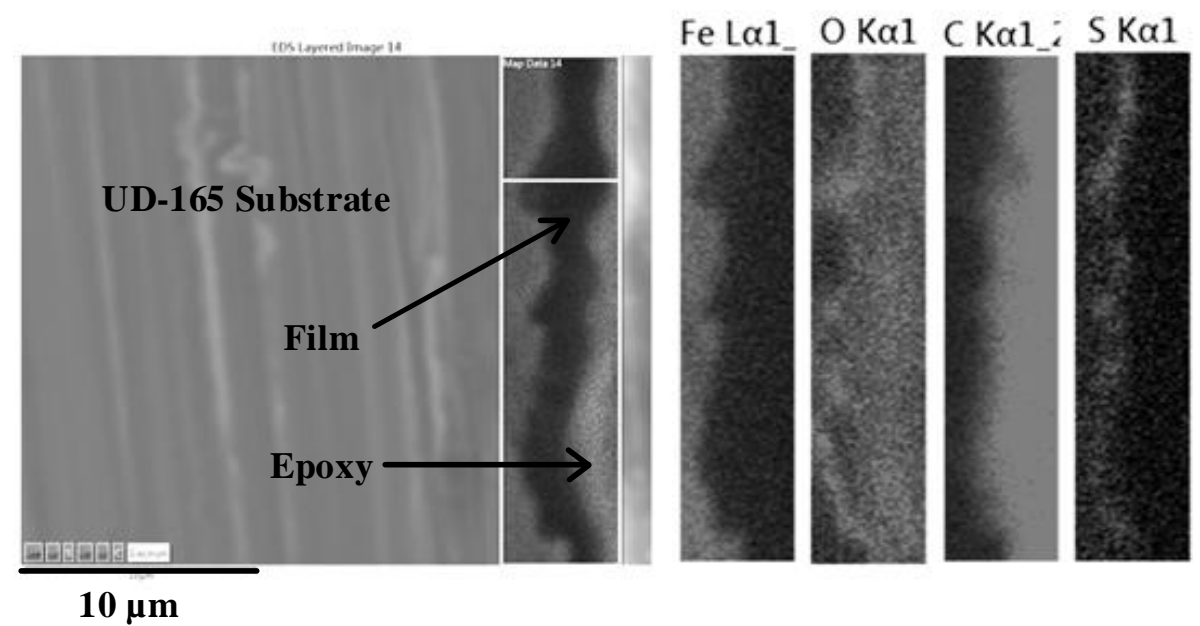

Fig. 13. EDS elemental maps of cross-section of UD-165 sample corroded in Solution \#1 at $p_{\mathrm{H} 2 \mathrm{~S}}$ $=0.83 \mathrm{kPa}\left(2.63 \times 10^{-4} \mathrm{~mol} \mathrm{~kg}{ }^{-1} \mathrm{H}_{2} \mathrm{~S}\right)$ and $85{ }^{\circ} \mathrm{C}$ for $\sim 84$ hours. Conditions: Solution \#1: $0.9 \mathrm{~mol}$ $\mathrm{kg}^{-1} \mathrm{NaCl}, 0.5 \mathrm{~mol} \mathrm{~kg}^{-1} \mathrm{NaHCO}_{3}, \mathrm{pH}=7.9$. The light-colored dots in each frame on the righthand side represent the corresponding element distribution. 

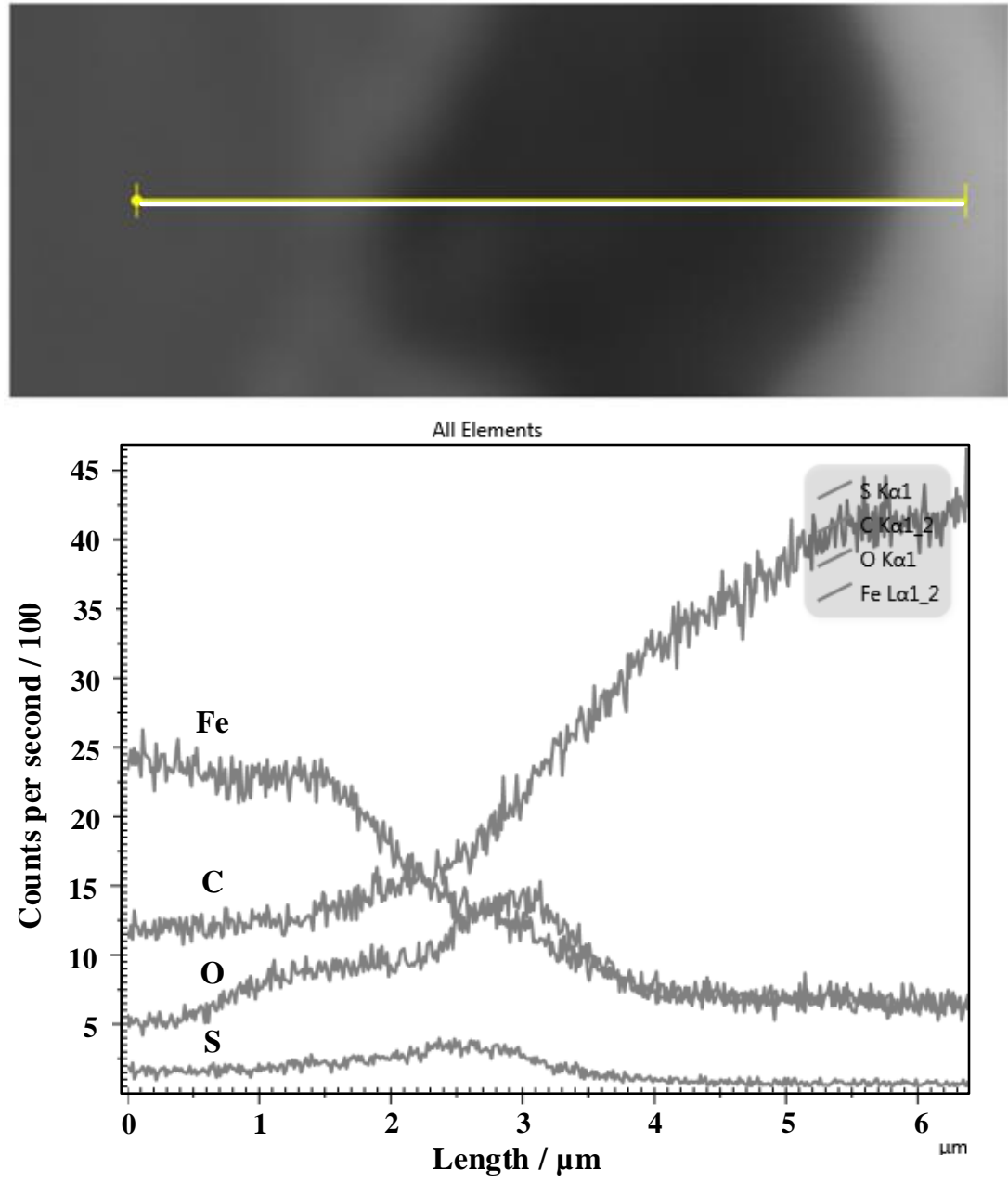

Fig. 14. EDS line scan result of cross-section of UD-165 sample corroded in Solution \#1 at $p_{\mathrm{H} 2 \mathrm{~S}}$ $=0.83 \mathrm{kPa}\left(2.63 \times 10^{-4} \mathrm{~mol} \mathrm{~kg}^{-1} \mathrm{H}_{2} \mathrm{~S}\right)$ and $85^{\circ} \mathrm{C}$ for $\sim 84$ hours. Conditions: Solution \#1: $0.9 \mathrm{~mol}$ $\mathrm{kg}^{-1} \mathrm{NaCl}, 0.5 \mathrm{~mol} \mathrm{~kg}^{-1} \mathrm{NaHCO}_{3}, \mathrm{pH}=$ 7.9. The scan line is also marked in Fig. 13 . 
Fig. 1. Schematic diagram of the autoclave system.

1- Connection to pressure transducer; 2- Heating mantle; 3- Autoclave stainless steel vessel; 4PTFE liner; 5- Polymer-coated thermocouple; 6- PEEK tubing; 7- Epoxy-coated stirrer; 8PTFE-coated electrode lead; 9- Ag/AgCl reference electrode; 10- PTFE assembly; 11- Steel working electrode; 12 - Pt counter electrode; $13-\mathrm{H}_{2} \mathrm{~S} / \mathrm{N}_{2}$ cylinder.

Fig. 2. Experimental $R_{\mathrm{pol}}$ after 60 hours in the three solutions at $p_{\mathrm{H} 2 \mathrm{~S}}=0 \mathrm{kPa}, 0.83 \mathrm{kPa}\left(2.63 \times 10^{-}\right.$ $\left.{ }^{4} \mathrm{~mol} \mathrm{~kg}^{-1} \mathrm{H}_{2} \mathrm{~S}\right), 8.3 \mathrm{kPa}\left(2.63 \times 10^{-3} \mathrm{~mol} \mathrm{~kg}^{-1} \mathrm{H}_{2} \mathrm{~S}\right)$, and $69 \mathrm{kPa}\left(2.19 \times 10^{-2} \mathrm{~mol} \mathrm{~kg}^{-1} \mathrm{H}_{2} \mathrm{~S}\right)$ at $85{ }^{\circ} \mathrm{C}$. Conditions: Solution \#1: $0.9 \mathrm{~mol} \mathrm{~kg}^{-1} \mathrm{NaCl}, 0.5 \mathrm{~mol} \mathrm{~kg}^{-1} \mathrm{NaHCO}_{3}, \mathrm{pH}=7.9$; Solution \#2: 0.9 mol kg ${ }^{-1} \mathrm{NaCl}, 1 \mathrm{~mol} \mathrm{~kg}{ }^{-1} \mathrm{Na}_{2} \mathrm{CO}_{3}, \mathrm{pH}=10.7$; Solution \#3: $0.9 \mathrm{~mol} \mathrm{~kg}{ }^{-1} \mathrm{NaCl}, 1 \mathrm{~mol} \mathrm{~kg}^{-1}$ $\mathrm{Na}_{2} \mathrm{CO}_{3}, 1 \mathrm{~mol} \mathrm{~kg}{ }^{-1} \mathrm{NaOH}, \mathrm{pH}=12.4$.

Fig. 3. Experimental corrosion rates after 60 hours in the three solutions at $p_{\mathrm{H} 2 \mathrm{~S}}=0 \mathrm{kPa}, 0.83$ $\mathrm{kPa}\left(2.63 \times 10^{-4} \mathrm{~mol} \mathrm{~kg}^{-1} \mathrm{H}_{2} \mathrm{~S}\right), 8.3 \mathrm{kPa}\left(2.63 \times 10^{-3} \mathrm{~mol} \mathrm{~kg}^{-1} \mathrm{H}_{2} \mathrm{~S}\right)$, and $69 \mathrm{kPa}\left(2.19 \times 10^{-2} \mathrm{~mol} \mathrm{~kg}^{-1}\right.$ $\mathrm{H}_{2} \mathrm{~S}$ ) at $85{ }^{\circ} \mathrm{C}$. Conditions: Solution \#1: $0.9 \mathrm{~mol} \mathrm{~kg}^{-1} \mathrm{NaCl}, 0.5 \mathrm{~mol} \mathrm{~kg}{ }^{-1} \mathrm{NaHCO}_{3}, \mathrm{pH}=7.9$; Solution \#2: $0.9 \mathrm{~mol} \mathrm{~kg}^{-1} \mathrm{NaCl}, 1 \mathrm{~mol} \mathrm{~kg} \mathrm{Na}_{2} \mathrm{CO}_{3}, \mathrm{pH}=10.7$; Solution \#3: 0.9 mol kg $\mathrm{NaCl}^{-1} 1$ mol kg ${ }^{-1} \mathrm{Na}_{2} \mathrm{CO}_{3}, 1 \mathrm{~mol} \mathrm{~kg}^{-1} \mathrm{NaOH}, \mathrm{pH}=12.4$.

Fig. 4. The Nyquist plots for UD-165 at different stir rates after being corroded for 60 hours in Solution \#2 at $p_{\mathrm{H} 2 \mathrm{~S}}=69 \mathrm{kPa}\left(2.19 \times 10^{-2} \mathrm{~mol} \mathrm{~kg}^{-1} \mathrm{H}_{2} \mathrm{~S}\right)$ at $85^{\circ} \mathrm{C}$. Conditions: Solution \#2: $0.9 \mathrm{~mol}$ $\mathrm{kg}^{-1} \mathrm{NaCl}, 1 \mathrm{~mol} \mathrm{~kg}{ }^{-1} \mathrm{Na}_{2} \mathrm{CO}_{3}, \mathrm{pH}=10.5$.

Fig. 5. The LSV plots of UD-165 at $p_{\mathrm{H} 2 \mathrm{~S}}=0 \mathrm{kPa}$ in the three solutions at $85^{\circ} \mathrm{C}$ with a sweep rate of $5 \mathrm{mV} \mathrm{s}^{-1}$. Conditions: Solution \#1: $0.9 \mathrm{~mol} \mathrm{~kg}^{-1} \mathrm{NaCl}, 0.5 \mathrm{~mol} \mathrm{~kg}{ }^{-1} \mathrm{NaHCO}_{3}, \mathrm{pH}=7.9$; Solution \#2: $0.9 \mathrm{~mol} \mathrm{~kg}{ }^{-1} \mathrm{NaCl}, 1 \mathrm{~mol} \mathrm{~kg} \mathrm{Na}_{2} \mathrm{CO}_{3}, \mathrm{pH}=10.7$; Solution \#3: $0.9 \mathrm{~mol} \mathrm{~kg} \mathrm{kaCl}^{-1} \mathrm{~N}$ mol kg-1 $\mathrm{Na}_{2} \mathrm{CO}_{3}, 1 \mathrm{~mol} \mathrm{~kg}{ }^{-1} \mathrm{NaOH}, \mathrm{pH}=12.4$. 
Fig. 6. The LSV plots of UD-165 at $p_{\mathrm{H} 2 \mathrm{~S}}=69 \mathrm{kPa}\left(2.19 \times 10^{-2} \mathrm{~mol} \mathrm{~kg}^{-1} \mathrm{H}_{2} \mathrm{~S}\right)$ in the three solutions at $85{ }^{\circ} \mathrm{C}$ with a sweep rate of $2 \mathrm{mV} \mathrm{s}^{-1}$. Conditions: Solution \#1: $0.9 \mathrm{~mol} \mathrm{~kg} \mathrm{NaCl}^{-1} 0.5$ mol kg ${ }^{-1} \mathrm{NaHCO}_{3}, \mathrm{pH}=7.7$; Solution \#2: $0.9 \mathrm{~mol} \mathrm{~kg}^{-1} \mathrm{NaCl}, 1 \mathrm{~mol} \mathrm{~kg}^{-1} \mathrm{Na}_{2} \mathrm{CO}_{3}, \mathrm{pH}=10.5$; Solution \#3: $0.9 \mathrm{~mol} \mathrm{~kg}^{-1} \mathrm{NaCl}, 1 \mathrm{~mol} \mathrm{~kg}^{-1} \mathrm{Na}_{2} \mathrm{CO}_{3}, 1 \mathrm{~mol} \mathrm{~kg}^{-1} \mathrm{NaOH}, \mathrm{pH}=12.4$.

Fig. 7. Nyquist (top) and Bode (bottom) plots of UD-165 samples after 60 hours in the three solutions at $p_{\mathrm{H} 2 \mathrm{~S}}=0 \mathrm{kPa}$ and $69 \mathrm{kPa}\left(2.19 \times 10^{-2} \mathrm{~kg} \mathrm{~mol}^{-1} \mathrm{H}_{2} \mathrm{~S}\right)$ at $85^{\circ} \mathrm{C}$. Conditions: Solution \#1: $0.9 \mathrm{~mol} \mathrm{~kg}{ }^{-1} \mathrm{NaCl}, 0.5 \mathrm{~mol} \mathrm{~kg}^{-1} \mathrm{NaHCO}_{3}, \mathrm{pH}=7.9$; Solution \#2: $0.9 \mathrm{~mol} \mathrm{~kg}{ }^{-1} \mathrm{NaCl}, 1 \mathrm{~mol} \mathrm{~kg}^{-1}$ $\mathrm{Na}_{2} \mathrm{CO}_{3}, \mathrm{pH}=10.7$; Solution \#3: $0.9 \mathrm{~mol} \mathrm{~kg}^{-1} \mathrm{NaCl}, 1 \mathrm{~mol} \mathrm{~kg}^{-1} \mathrm{Na}_{2} \mathrm{CO}_{3}, 1 \mathrm{~mol} \mathrm{~kg}^{-1} \mathrm{NaOH}, \mathrm{pH}=$ 12.4. The symbols represent the experimental EIS results and the lines represent the fitting results based on the equivalent circuits in Fig. 8.

Fig. 8. The equivalent electrical circuits to fit the EIS data at $p_{\mathrm{H} 2 \mathrm{~S}}=0 \mathrm{kPa}$ and $69 \mathrm{kPa}\left(2.19 \times 10^{-2}\right.$ mol kg-1 $\mathrm{H}_{2} \mathrm{~S}$ ) at $85^{\circ} \mathrm{C}$. Circuit (a) for Solutions \#1 and \#3 and (b) for Solution \#2 in Fig. 7. Conditions: Solution \#1: $0.9 \mathrm{~mol} \mathrm{~kg}^{-1} \mathrm{NaCl}, 0.5 \mathrm{~mol} \mathrm{~kg}^{-1} \mathrm{NaHCO}_{3}, \mathrm{pH}=7.9$; Solution \#2: 0.9 mol kg ${ }^{-1} \mathrm{NaCl}, 1 \mathrm{~mol} \mathrm{~kg}^{-1} \mathrm{Na}_{2} \mathrm{CO}_{3}, \mathrm{pH}=10.7$; Solution \#3: $0.9 \mathrm{~mol} \mathrm{~kg}{ }^{-1} \mathrm{NaCl}, 1 \mathrm{~mol} \mathrm{~kg}^{-1}$ $\mathrm{Na}_{2} \mathrm{CO}_{3}, 1 \mathrm{~mol} \mathrm{~kg}{ }^{-1} \mathrm{NaOH}, \mathrm{pH}=12.4$.

Fig. 9. Pourbaix diagram for $\mathrm{Fe}-\mathrm{H}_{2} \mathrm{O}-\mathrm{H}_{2} \mathrm{CO}_{3}$ system in Solution $\# 2$ at $p_{\mathrm{H} 2 \mathrm{~S}}=0 \mathrm{kPa}$ and $85{ }^{\circ} \mathrm{C}$. Conditions: $2.9 \mathrm{~mol} \mathrm{~kg}^{-1} \mathrm{Na}^{+}(\mathrm{aq}), 0.9 \mathrm{~mol} \mathrm{~kg}{ }^{-1} \mathrm{Cl}^{-}(\mathrm{aq}), 1 \mathrm{~mol} \mathrm{~kg}^{-1} \mathrm{CO}_{3}{ }^{2-}(\mathrm{aq}), \mathrm{pH}=10.7$; the activity of $\mathrm{Fe}^{2+}(\mathrm{aq})$ was assumed to be $10^{-6}$; Titrants: $\mathrm{NaOH} / \mathrm{HCl}$.

Fig. 10. Pourbaix diagram for $\mathrm{Fe}-\mathrm{H}_{2} \mathrm{O}-\mathrm{H}_{2} \mathrm{CO}_{3}-\mathrm{H}_{2} \mathrm{~S}$ system in Solution $\# 2$ at $p_{\mathrm{H} 2 \mathrm{~S}}=69 \mathrm{kPa}$ $\left(2.19 \times 10^{-2} \mathrm{~mol} \mathrm{~kg}^{-1} \mathrm{H}_{2} \mathrm{~S}\right)$ and $85{ }^{\circ} \mathrm{C}$. Conditions: $2.9 \mathrm{~mol} \mathrm{~kg}{ }^{-1} \mathrm{Na}^{+}(\mathrm{aq}), 0.9 \mathrm{~mol} \mathrm{~kg}^{-1} \mathrm{Cl}^{-}(\mathrm{aq}), 1 \mathrm{~mol}$ $\mathrm{kg}^{-1} \mathrm{CO}_{3}{ }^{2-}(\mathrm{aq}), \mathrm{pH}=10.5$; the activity of $\mathrm{Fe}^{2+}(\mathrm{aq})$ was assumed to be $10^{-6}$; Titrants: $\mathrm{NaOH} / \mathrm{HCl}$. Fig. 11. SEM images of UD-165 steel surfaces after the corrosion tests $(\sim 84$ hours $)$ at $p_{\mathrm{H} 2 \mathrm{~S}}=0$ $\mathrm{kPa}$ and $85^{\circ} \mathrm{C}$. A - Solution \#1: $0.9 \mathrm{~mol} \mathrm{~kg}^{-1} \mathrm{NaCl}, 0.5 \mathrm{~mol} \mathrm{~kg}^{-1} \mathrm{NaHCO}_{3}, \mathrm{pH}=7.9$; $\mathrm{B}$ - Solution 
\#2: $0.9 \mathrm{~mol} \mathrm{~kg}^{-1} \mathrm{NaCl}, 1 \mathrm{~mol} \mathrm{~kg}^{-1} \mathrm{Na}_{2} \mathrm{CO}_{3}, \mathrm{pH}=10.7$; C - Solution \#3: $0.9 \mathrm{~mol} \mathrm{~kg}^{-1} \mathrm{NaCl}, 1 \mathrm{~mol}$ $\mathrm{kg}^{-1} \mathrm{Na}_{2} \mathrm{CO}_{3}, 1 \mathrm{~mol} \mathrm{~kg}^{-1} \mathrm{NaOH}, \mathrm{pH}=12.4$.

Fig. 12. SEM images of UD-165 steel surfaces after the corrosion tests ( $\sim 84$ hours) at $p_{\mathrm{H} 2 \mathrm{~S}}=69$ $\mathrm{kPa}\left(2.19 \times 10^{-2} \mathrm{~mol} \mathrm{~kg}^{-1} \mathrm{H}_{2} \mathrm{~S}\right)$ and $85^{\circ} \mathrm{C}$. A - Solution \#1: $0.9 \mathrm{~mol} \mathrm{~kg}^{-1} \mathrm{NaCl}, 0.5 \mathrm{~mol} \mathrm{~kg}^{-1}$ $\mathrm{NaHCO}_{3}, \mathrm{pH}=7.7$; $\mathrm{B}$ - Solution \#2: $0.9 \mathrm{~mol} \mathrm{~kg}^{-1} \mathrm{NaCl}, 1 \mathrm{~mol} \mathrm{~kg}^{-1} \mathrm{Na}_{2} \mathrm{CO}_{3}, \mathrm{pH}=10.5 ; \mathrm{C}$ and D Solution \#3: $0.9 \mathrm{~mol} \mathrm{~kg}^{-1} \mathrm{NaCl}, 1 \mathrm{~mol} \mathrm{~kg}^{-1} \mathrm{Na}_{2} \mathrm{CO}_{3}, 1 \mathrm{~mol} \mathrm{~kg}^{-1} \mathrm{NaOH}, \mathrm{pH}=12.4$.

Fig. 13. EDS elemental maps of cross-section of UD-165 sample corroded in Solution \#1 at $p_{\mathrm{H} 2 \mathrm{~S}}$ $=0.83 \mathrm{kPa}\left(2.63 \times 10^{-4} \mathrm{~mol} \mathrm{~kg}{ }^{-1} \mathrm{H}_{2} \mathrm{~S}\right)$ and $85{ }^{\circ} \mathrm{C}$ for $\sim 84$ hours. Conditions: Solution \#1: $0.9 \mathrm{~mol}$ $\mathrm{kg}^{-1} \mathrm{NaCl}, 0.5 \mathrm{~mol} \mathrm{~kg}{ }^{-1} \mathrm{NaHCO}_{3}, \mathrm{pH}=7.9$. The light-colored dots in each frame on the righthand side represent the corresponding element distribution.

Fig. 14. EDS line scan result of cross-section of UD-165 sample corroded in Solution \#1 at $p_{\mathrm{H} 2 \mathrm{~S}}$ $=0.83 \mathrm{kPa}\left(2.63 \times 10^{-4} \mathrm{~mol} \mathrm{~kg}^{-1} \mathrm{H}_{2} \mathrm{~S}\right)$ and $85^{\circ} \mathrm{C}$ for $\sim 84$ hours. Conditions: Solution \#1: $0.9 \mathrm{~mol}$ $\mathrm{kg}^{-1} \mathrm{NaCl}, 0.5 \mathrm{~mol} \mathrm{~kg}^{-1} \mathrm{NaHCO}_{3}, \mathrm{pH}=7.9$. The scan line is also marked in Fig. 13. 